\title{
EXCHANGE RATE DYNAMICS AND UNITED STATES DOLLAR- DENOMINATED SOVEREIGN BOND PRICES IN EMERGING MARKETS
}

Cho-Hoi Hui, Chi-Fai Lo, and Po-Hon Chau

NO. 530

December 2017
ADB ECONOMICS WORKING PAPER SERIES 
ADB Economics Working Paper Series

\section{Exchange Rate Dynamics and United States Dollar-Denominated Sovereign Bond Prices in Emerging Markets}

Cho-Hoi Hui, Chi-Fai Lo, and Po-Hon Chau

No. 530 | December 2017
Cho-Hoi Hui (chhui@hkma.gov.hk), is head of Market Research Division in the Research Department of the Hong Kong Monetary Authority and Adviser at the Hong Kong Institute for Monetary Research. Chi-Fai Lo (cflo@phy.cuhk.edu.hk) is an associate professor at the Department of Physics, Chinese University of Hong Kong. Po-Hon Chau (phchau@phy.cuhk.edu.hk) is from the Institute of Theoretical Physics and Department of Physics of the Chinese University of Hong Kong.

This paper was presented at the 2016 ADB-UNSW International Conference on Financial Cycles, Systemic Risk, Interconnectedness, and Policy Options for Resilience, in connection with the preparation of the theme chapter of the Asian Economic Integration Report 2017. A similar version appears as Hong Kong Institute for Monetary Research Working Paper No.07/2016. The views expressed in this paper are the authors' and do not necessarily represent those of the Hong Kong Monetary Authority and the Chinese University of Hong Kong. 
(c) 2017 Asian Development Bank

6 ADB Avenue, Mandaluyong City, 1550 Metro Manila, Philippines

Tel +632632 4444; Fax +6326362444

www.adb.org

Some rights reserved. Published in 2017

ISSN 2313-6537 (Print), 2313-6545 (electronic)

Publication Stock No. WPS179151-2

DOI: http://dx.doi.org/10.22617/WPS179151-2

The views expressed in this publication are those of the authors and do not necessarily reflect the views and policies of the Asian Development Bank (ADB) or its Board of Governors or the governments they represent.

ADB does not guarantee the accuracy of the data included in this publication and accepts no responsibility for any consequence of their use. The mention of specific companies or products of manufacturers does not imply that they are endorsed or recommended by ADB in preference to others of a similar nature that are not mentioned.

By making any designation of or reference to a particular territory or geographic area, or by using the term "country" in this document, $A D B$ does not intend to make any judgments as to the legal or other status of any territory or area.

This work is available under the Creative Commons Attribution 3.0 IGO license (CC BY 3.0 IGO)

https://creativecommons.org/licenses/by/3.0/igo/. By using the content of this publication, you agree to be bound by the terms of this license. For attribution, translations, adaptations, and permissions, please read the provisions and terms of use at https://www.adb.org/terms-use\#openaccess

This CC license does not apply to non-ADB copyright materials in this publication. If the material is attributed to another source, please contact the copyright owner or publisher of that source for permission to reproduce it. $A D B$ cannot be held liable for any claims that arise as a result of your use of the material.

Please contact pubsmarketing@adb.org if you have questions or comments with respect to content, or if you wish to obtain copyright permission for your intended use that does not fall within these terms, or for permission to use the ADB logo.

Notes:

1. In this publication, " $\$$ " refers to US dollars.

2. ADB recognizes "Hong Kong" as Hong Kong, China.

3. Corrigenda to ADB publications may be found at http://www.adb.org/publications/corrigenda 


\section{CONTENTS}

TABLES AND FIGURES

ABSTRACT $v$ V

$\begin{array}{ll}\text { I. INTRODUCTION } & 1\end{array}$

II. RELATIONSHIPS AMONG DOLLAR-DENOMINATED SOVEREIGN BOND SPREADS, FOREIGN EXCHANGE RATES, AND UNITED STATES TREASURY YIELDS 4

III. DOLLAR-DENOMINATED SOVEREIGN BOND PRICING MODEL 9

A. $\quad$ Risk-Free Interest Rate Dynamics 9

B. Valuation of United States Dollar-Denominated Sovereign Bonds 11

IV. MARKET AND MODEL-IMPLIED SOVEREIGN BOND CREDIT SPREADS

A. Parameters for Pricing Bonds 13

B. Predicted Spreads from the Model 16

C. Error Analysis 19

$\begin{array}{ll}\text { V. CONCLUSIONS } & 24\end{array}$

$\begin{array}{ll}\text { APPENDIX } & 25\end{array}$

$\begin{array}{lr}\text { REFERENCES } & 27\end{array}$ 


\section{TABLES AND FIGURES}

\section{TABLES}

1 Summary Statistics on Sample Bonds, Exchange Rates, and Option-Implied Volatility

2 Regression Results for Daily Credit Spread Changes in Treasury Yields and Exchange Rates

3 Generalized Method of Moments Estimates of the DSR Model 15

$4 \quad$ Levels of Default Barriers, Precrisis and Postcrisis 15

5 Correlations between Market and Model Credit Spreads, Precrisis and Postcrisis 19

6 Performances of the Model, Precrisis and Postcrisis

\section{FIGURES}

1 Dollar-Denominated Sovereign Bond Credit Spreads of Emerging Market Countries

2 Exchange Rates and Option-Implied Volatility of Emerging Market Currencies

3 Comparison of Model and Market Sovereign Bond Credit Spreads 


\begin{abstract}
The study conducts an empirical test on dollar-denominated sovereign credit spreads in emerging markets, including Brazil, Colombia, Mexico, the Philippines, the Russian Federation, and Turkey to examine their relationship with each country's exchange rate and the United States (US) Treasury yields. The relationship between each country's exchange rate and the pricing of each country's US-dollar denominated sovereign bonds was particularly strong after the global financial crisis of 2008-2009. A two-factor pricing model is developed with closed-form solutions for the sovereign bonds. The correlated factors in the model are foreign exchange rates and US risk-free interest rates that follow a double square-root process relevant in a low interest rate environment. The numerical results and associated error analysis show that the model credit spreads can broadly track market credit spreads.
\end{abstract}

Keywords: bond pricing model, emerging markets, exchange rates, sovereign risk

JEL codes: G13, G21, G28 


\section{INTRODUCTION}

The relationship between sovereign risk and exchange rate stability has long been a subject of interest in international finance. Papers on the subject include Eichengreen, Rose, and Wyplosz (1996); Frankel and Rose (1996); Kaminsky, Lizondo, and Reinhart (1998); and Kumar, Moorthy, and Perraudin (2003), who use macroeconomic indicators to estimate the probability of currency crashes. On the empirical side, Reinhart (2002), finds that $84 \%$ of the defaults in her emerging markets sample are connected with currency crises and almost half of the currency crises in the sample are related to defaults. Herz and Tong (2008) find that $32 \%$ of all debt crises in emerging markets are linked to currency crises, while $20 \%$ of currency crises are associated with debt crises. Dreher, Herz, and Karb (2006) study the empirical relationship between currency and sovereign debt crises, covering 80 countries over 1975-2000, and find that currency crisis is more likely to occur when there is a contemporaneous debt crisis, and vice versa. Empirically, twin debt and currency crises occur more frequently than twin banking and currency crises.

The dynamic linkage between sovereign credit risk and exchange rates has been studied for emerging markets. Carr and Wu (2007) investigate the connection between currency option-implied volatilities and sovereign creditworthiness for Mexico and Brazil from 2002 to 2005. They find that the level and skew of the option-implied volatility display significant comovement with the sovereign creditdefault swap (CDS) spreads of the two countries. Pan and Singleton (2008) explore the term structure of CDS spreads for Mexico, Turkey, and the Republic of Korea from 2001 to 2006 and consider the riskneutral credit event intensities and loss rates that best describe the CDS data. Their results suggest that currency option volatilities may have served as a proxy for the fundamental macroeconomic and event risks embodied in the CBOE Volatility Index (VIX). ' Pavlova and de Boyrie (2015) find information flows between currency carry-trade returns of nine economies in the Asia and Pacific and changes in the Markit iTraxx SovX Asia Pacific index from 2008 to 2011, which are negatively correlated. ${ }^{2}$

While sovereign risk and exchange rate stability have been studied in the context of sovereign debt crises, the literature on the empirical determinants of sovereign bond yield spreads usually focus on variables other than exchange rates. Some papers, including Edwards (1986), Eichengreen and Mody (2000), Min (1998), Beck (2001), and Ferrucci (2003), concentrate on reduced form regressions of spreads on a large set of macroeconomic variables. Gross domestic product (GDP) growth, inflation, and United States (US) Treasury yields are found to be important explanatory variables. Duffie, Pedersen, and Singleton (2003) develop a flexible reduced form model of sovereign yield spreads. They estimate their model using weekly data on Russian dollar-denominated debt and US swap yields between 1994 and 1998. The study relates spreads implied by the model to political factors, foreign exchange reserves, oil prices, and the VIX. Longstaff et al. (2011) demonstrate that US stock and bond market returns, and global volatility, can explain much of the variation in sovereign CDS spreads. Hilscher and Nosbusch (2010) investigate the effects of macroeconomic fundamentals on emerging market sovereign credit spreads and find that terms of trade volatility in particular has a statistically and economically significant effect on spreads. Jeanneret (2015) proposes a model which generates daily sovereign credit spreads using expected economic conditions, which are structurally extracted from the local stock market.

To price sovereign risky bonds based on exchange rate dynamics, Cathcart and El-Jahel (1998) propose a model in which default occurs when some signaling process hits a constant default barrier.

\footnotetext{
VIX is the market volatility of the US S\&P 500 index which gauges the global risk appetite in the financial market.

2 Carry trades are speculative investment strategies in the foreign exchange market, where investors borrow low yielding (funding) currencies and invest in high yielding (investment) currencies.
} 
The signal can be factors affecting the probability of default, such as the GDP growth rate or an exchange rate. ${ }^{3}$ Claessens and Pennacchi (1996) use a similar framework to price Mexican Brady bonds. Hui and Lo (2002) price US dollar-denominated bonds sold by the Republic of Korea and Brazilian governments with a model in which the nominal exchange rate signals default. Rocha and Alcaraz Garcia (2005) propose a similar model in which signaling for default depends on the real exchange rate, and apply the model to price Brazilian, Mexican, Russian, and Turkish sovereign bonds. While all of these models allow for stochastic interest rates using mainly the Cox-Ingersoll-Ross (CIR) model from 1985, the correlation between the signal and interest rates is assumed to be zero. The empirical studies of these models used data from the 1990s, when the Asian financial crisis 1997-1998 occurred.

In the aftermath of the global financial crisis in 2008, capital inflows to emerging markets surged, and they have been volatile since then. At the same time, the US Federal Reserve lowered its policy interest rate to the zero lower bound. The empirical results presented in this paper demonstrate that exchange rates and US interest rates were significant determinants of credit spreads on dollardenominated sovereign bonds of Brazil, Colombia, Mexico, the Philippines, the Russian Federation, and Turkey before the crisis, and remain so after. In view of such market development, this paper studies the dynamic linkage between US dollar-denominated sovereign bond prices and exchange rates in emerging markets by deriving a two-factor risky bond pricing model with closed-form solutions in which the exchange rate and the US risk-free interest rate are the underlying factors. The currency option-implied volatility is used as the associated model parameter of the exchange rate to incorporate forward-looking market information into the model.

In the proposed model, a currency's exchange rate, i.e., the US dollar price of the local currency, is analogous to the stock price by using an analogy between corporate valuation and budget constraints for an economy, as proposed by Sims (1999) and Cochrane (2005). The analogy assumes that the exchange rate adequately reflects country fundamentals anticipated in the market, similar to a firm's value measured by its stock price. ${ }^{4}$ The exchange rate in the proposed model is therefore structural in nature instead of being a signal used in the previous models. The proposed model incorporates two features that differ from the previous models. First, the correlation between the exchange rate and riskfree interest rate is explicitly incorporated into the model and its closed-form solutions. Therefore, their dynamic linkage which is absent in the previous models is fully reflected in the proposed model. Secondly, the stochastic risk-free interest rate in the proposed model is assumed to follow the double square-root (DSR) process proposed by Longstaff (1989). One important characteristic of the DSR model is that it has a nonlinear restoring force in its drift term such that the interest rate is sticky downward. It is therefore particularly relevant to the low interest rate environment since the global financial crisis in 2008, with the short-term interest rate tending to persist near the zero bound instead of moving back toward higher rates in a short time as implied by the CIR model and Vasicek (1977) models conventionally used in risky bond pricing models. ${ }^{5}$

3 Moraux (2004) solves the model of Cathcart and El-Jahel (1998) in closed form.

4 This is also consistent with the basic log linear model of the exchange rate on which most of the target-zone literature, such as Krugman (1991) is based for a small open economy. In the model, the exchange rate is equal to fundamentals plus a term proportional to the expected change in the log exchange rate.

5 Following the bankruptcy of Lehman Brothers in September 2008, developments took a dramatic turn and spilled over to other economies. During 2008, the US Federal Reserve (Fed) lowered the policy rate from 4\% to 0-0.25\% to provide monetary support for the economy. Subsequently, it has taken unprecedented measures, including quantitative easing policies that have lowered long-term borrowing costs and fostered economic activity. As the interest rate term structure was affected by the Fed's ultra-accommodative monetary policy, the 3-month US Treasury bill yield has fallen to near zero for an extended period. The 10-year Treasury yield has been falling and hit the historical low of $1.32 \%$ in July 2016 , even after the Fed raised the policy rate by $0.25 \%$ in December 2015. 
The risky bond pricing model used in this paper follows a structural framework for pricing corporate bonds proposed by Black and Scholes (1973) and Merton (1974). In the Black-ScholesMerton structural framework, the capital structure is explicitly considered and default happens if the total asset value is lower than the value of liabilities at the bond's maturity. Default risk is therefore equivalent to a European put option on a firm's asset value. From a microeconomic perspective, such structural framework can be applied to price sovereign dollar-denominated bonds. A firm can be considered as an entity which issues two different classes of securities-a single homogeneous debt consisting of a zero-coupon bond and a residual claim, i.e., equity. In the balance sheet of the firm, the total value of its assets is equal to the sum of the values of a zero-coupon bond and equity. Under the Modigliani and Miller (1958) proposition, corporate debt and equity sum to the present value of future earnings, and the firm's total asset value is independent of this capital structure decision. Sims (1999) and Cochrane (2005) propose an analogy between corporate valuation and budget constraints for an economy.

The analogy is as follows. On the balance sheet of an economy, foreign and domestic debt sum to the present value of the future budget surplus. Foreign debt of the economy is the "actual" debt, while domestic debt and fiat money act like equity in a firm. Given that the government promises only to pay the domestic debt in local currency in the future, the function of domestic debt is to absorb fiscal risk by the adjustment of its foreign currency (e.g., US dollar) equivalent value. In other words, solvency can be restored through devaluation of nominal debt, created by currency depreciation. As long as there is some probability that the government will run a primary surplus in the future and/or will repurchase domestic currency debt, then such debt has value. Furthermore, the currency price, e.g., the US dollar price of the local currency, is analogous to the stock price. Similar to a firm facing risk of insolvency as its equity value slumps when instability is anticipated in the economy, the currency devalues when volatility rises and the credit quality of the economy deteriorates. Assuming efficient markets, this analogy suggests a positive linkage between sovereign foreign debt credit spreads and currency return/volatilities, analogous to the linkage identified between corporate credit spreads and stock return/volatilities. The proposed risky bond pricing model, in which the exchange rate is the underlying factor, can therefore be considered as a semistructural approach. The focus here is to explore directly through the bond pricing model the extent to which exchange rate dynamics incorporated with option-implied volatility determine dollar-denominated sovereign bond spreads.

Following the Black-Scholes-Merton's corporate bond pricing framework, subsequent studies extend the framework to incorporate a general default triggering mechanism which is considered as the first time the value of a firm's assets are lower than a default (constant or deterministic) barrier. ${ }^{6}$ Applying the above analogy between a firm and an economy, the US dollar price of local currency should indicate the credit quality of the economy, i.e., the ability to repay foreign debt. Similarly, a default barrier is associated with the currency value in the proposed semistructural model. As in the framework developed by Duffie and Lando (2001), if the dynamics of the exchange rate are treated as a hazard rate process, which governs an inaccessible default stopping time, the proposed model can be recast as a special case of "reduced-form models."

The stochastic risk-free interest rate in the proposed model follows the DSR process. Some empirical findings support the DSR model. The empirical results in Longstaff (1989) suggest that, by

6 To have more accurate measures of the default probability, subsequent studies mainly focus on the liability structure such that models with more complex and dynamic liability structures including Jones, Mason, and Rosenfeld (1984); Leland and Toft (1996); Longstaff and Schwartz (1995); Collin-Dufresne and Goldstein (2001); and Hui, Lo, and Tsang (2003) have been developed. 
estimating the model parameters, the DSR model is more successful than the CIR model in capturing the level and variation of 6- to 12-month Treasury bill yields during 1964-1986. The results also suggest that yields are nonlinearly related to the risk-free interest rate, as the model implies. Similarly, the estimations of the DSR model parameters presented in section IV.A below show that data on the Treasury bill and notes during January 2000 to September 2014 could fit the model. Ahn, Dittmar, and Gallant (2002) test the empirical performance of the quadratic term structure models, including the DSR model, in explaining historical bond price behavior in the US from December 1946 to February 1991. They find the quadratic term structure models outperform the affine term structure models, including the CIR and Vasicek models. Similar results are found by Leippold and Wu (2003), and Li and Zhao (2006). Ait-Sahalia (1996) shows that there is evidence of nonlinearities in the drift function of the interest rate term structure using a nonparametric approach. During the period of Japan's near-zero short-term rates in 2001-2005, Kim and Singleton (2012) find that the quadratic dynamic term structure models capture some of the key features of data on the Japanese Government Bond, including the variation in bond yields, and bond risk premiums that are very small when the interest rate is low.

The following section examines the empirical relationship among the exchanges rates and US dollar-denominated sovereign bond spreads of emerging markets (including Brazil, Colombia, Mexico, the Philippines, the Russian Federation, and Turkey) and the US Treasury yields. Section III shows the development of the US dollar-denominated sovereign bond pricing model under a semistructuralmodel framework. Section IV shows a study of the credit spreads of the sample of emerging markets, calculated from the model and then compared with actual market data. Section $\vee$ concludes.

\section{RELATIONSHIPS AMONG DOLLAR-DENOMINATED SOVEREIGN BOND SPREADS, FOREIGN EXCHANGE RATES, AND UNITED STATES TREASURY YIELDS}

In this section, an empirical test is conducted on dollar-denominated sovereign credit spreads in emerging markets, including Brazil, Colombia, Mexico, the Philippines, the Russian Federation, and Turkey, to study their relationship with each country's exchange rate and the yields on US Treasuries. These countries are selected because of their relatively liquid dollar-denominated bond markets. Daily data are obtained on sovereign bond yields from 1 June 2003 to 29 September 2014. Based on data availability, the tenors of the bonds are as follows: Brazil, Mexico, and Turkey (10-year, 15-year, 20-year, and 30-year tenors); Colombia (10-year and 30-year tenors); the Philippines (10-year, 15-year, and 20year tenors); and the Russian Federation (15-year tenor). Bond credit spreads, which are the difference between bond yields and US Treasury yields with a corresponding tenor, are illustrated in Figure 1. The credit spreads of sample countries declined from relatively high levels at the end of the regional financial crises in 2003 but then surged during the global financial crisis in 2008. They subsequently fell substantially in 2009 and then were traded in the range of about $0.5 \%-4 \%$. Given the illiquid sovereign bond markets during the global financial crisis in 2008 and the structural differences before and after the onset of the crisis, the sample is split into two periods. The first period is from 1 June 2003 to 31 December 2007 (i.e., precrisis), and the second is from 1 January 2009 to 29 September 2014 (i.e., postcrisis). ${ }^{7}$

7 The data are from Bloomberg. For the Philippines, data are only available for the bonds with 10-year and 20-year tenors in the postcrisis period. 


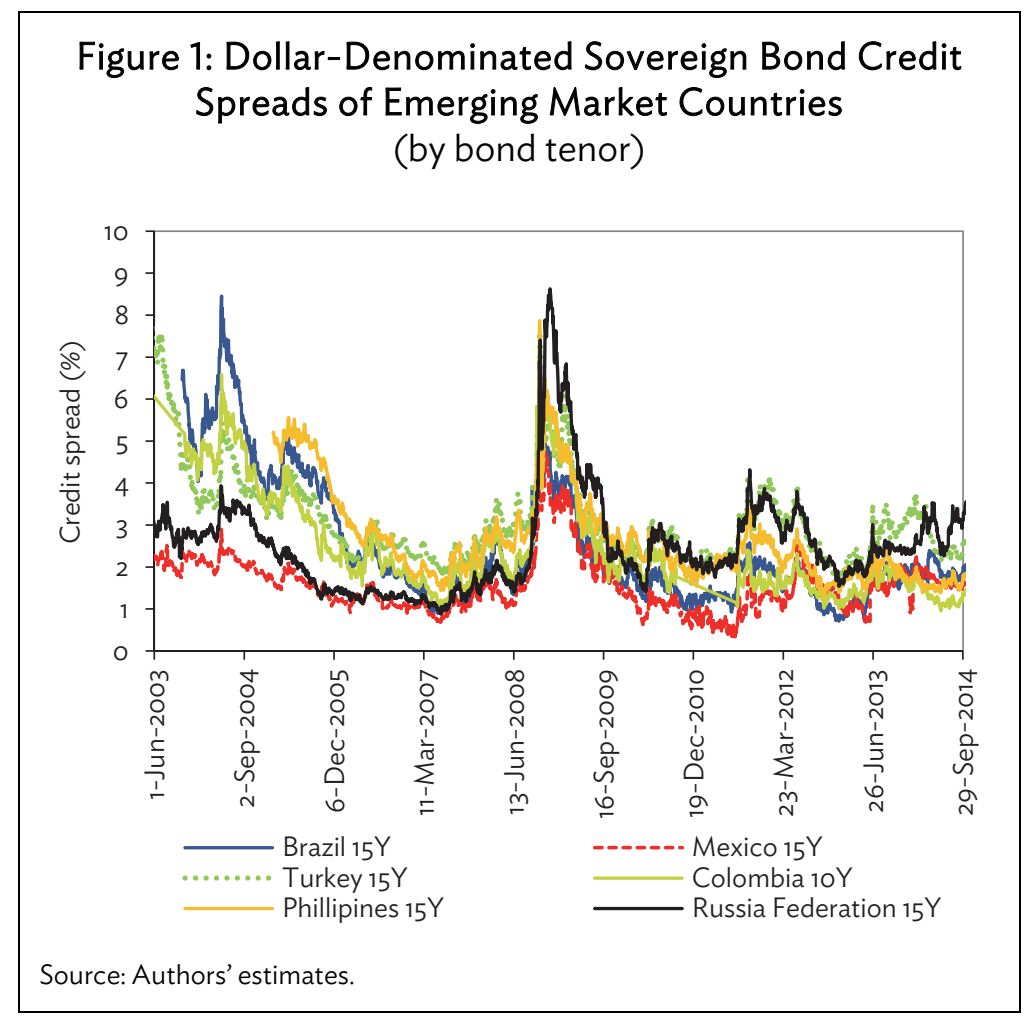

As a factor for change in interest rates, changes in Treasury yields of a corresponding tenor are used. Let $\triangle C S$ denote the change in the credit spread, $\Delta Y$ denote the change in the Treasury yield and $I$ denote the change in the exchange rate of the corresponding country. The regression equation is given by:

$$
\Delta C S=a+b \Delta I+c \Delta Y+\varepsilon
$$

where $a, b$, and $c$ are regression coefficients. The descriptive statistics of the variables are reported in Table 1. Movements in the exchange rate of the sample of countries shown in Figure 2 are quite similar to changes in their sovereign bond spreads.

Table 2 reports the regression results. The coefficients $b$ for all the countries are statistically significant at the $1 \%$ level and suggest a positive relationship between credit spreads and exchange rates. This is consistent with the expected sign that credit spreads increase with weaker currencies (i.e., higher exchange rates per dollar). The magnitude of the estimates of $b$ shows that the relation between credit spreads and interest rates is economically significant. For example, the regression results for Brazil imply that a 0.1 rise in the USD/BRL exchange rate (which has the mean of 2.44 in the precrisis period) increases the 30-year bond spread by 26 basis points in the precrisis period and 10 basis points in the postcrisis period. The difference between the effects of the exchange rate in the two periods is due to lower credit spreads in the postcrisis period (the mean of the credit spreads is $3.64 \%$ and $1.96 \%$ in the precrisis and postcrisis periods as shown in Table 1). There are similar observations for the other countries. The empirical results show a strong linkage between the sovereign credit spreads and exchange rates. 
6 | ADB Economics Working Paper Series No. 530

Table 1: Summary Statistics on Sample Bonds, Exchange Rates, and Option-Implied Volatility

\begin{tabular}{|c|c|c|c|c|c|c|c|c|}
\hline \multirow[b]{2}{*}{ Brazil } & \multicolumn{2}{|c|}{ Max } & \multicolumn{2}{|c|}{ Min } & \multicolumn{2}{|c|}{ Mean } & \multicolumn{2}{|c|}{ Standard Deviation } \\
\hline & Precrisis & Postcrisis & Precrisis & Postcrisis & Precrisis & Postcrisis & Precrisis & Postcrisis \\
\hline Bond spread 10Y (\%) & 8.8577 & 4.4195 & 0.9635 & 0.6473 & 3.5827 & 1.7503 & 1.9283 & 0.7182 \\
\hline Bond spread $15 Y(\%)$ & 8.4530 & 4.2563 & 0.8996 & 0.7070 & 3.4004 & 1.8832 & 1.8107 & 0.6844 \\
\hline Bond spread 20Y (\%) & 8.7270 & 4.4560 & 0.8730 & 0.9810 & 3.5393 & 2.0319 & 1.8349 & 0.7148 \\
\hline Bond spread 30Y (\%) & 8.6911 & 3.9394 & 1.1196 & 0.6178 & 3.6430 & 1.9588 & 1.7895 & 0.7245 \\
\hline Exchange rate USD/BRL & 3.2118 & 3.8415 & 1.7320 & 1.5387 & 2.4431 & 2.0954 & 0.4014 & 0.4282 \\
\hline Implied volatility (\%) & 26.125 & 41.425 & 9.5000 & 9.0500 & 15.6212 & 17.6596 & 3.0692 & 4.9606 \\
\hline \multicolumn{9}{|l|}{ Mexico } \\
\hline Bond spread 10Y (\%) & 2.3667 & 4.2861 & 0.6882 & 0.6349 & 1.3393 & 1.4691 & 0.3307 & 0.6967 \\
\hline Bond spread $15 Y(\%)$ & 2.9160 & 3.9521 & 0.6916 & 0.3119 & 1.5674 & 1.5189 & 0.4808 & 0.6294 \\
\hline Bond spread 20Y (\%) & 2.6470 & 4.1130 & 0.9480 & 0.9880 & 1.6564 & 1.7462 & 0.3848 & 0.5078 \\
\hline Bond spread 30Y (\%) & 2.8581 & 4.2509 & 0.8760 & 0.8778 & 1.8034 & 1.6958 & 0.4330 & 0.5407 \\
\hline Exchange rate USD/MXN & 11.664 & 17.201 & 10.247 & 11.493 & 10.987 & 13.216 & 0.2719 & 0.9856 \\
\hline Implied volatility (\%) & 13.430 & 39.900 & 6.6503 & 7.2500 & 8.6008 & 15.237 & 1.2371 & 4.9398 \\
\hline \multicolumn{9}{|l|}{ Turkey } \\
\hline Bond spread 10Y (\%) & 7.5787 & 6.8843 & 1.5221 & 1.1503 & 3.1713 & 2.4952 & 1.2667 & 0.8759 \\
\hline Bond spread $15 Y(\%)$ & 7.5601 & 6.1952 & 1.8266 & 1.5637 & 3.3764 & 2.7566 & 1.2055 & 0.7108 \\
\hline Bond spread 20Y (\%) & 3.5580 & 5.7610 & 1.7760 & 1.1170 & 2.4748 & 2.5389 & 0.4280 & 0.6876 \\
\hline Bond spread 30Y (\%) & 7.0480 & 6.5044 & 1.9971 & 1.0967 & 3.1377 & 2.5457 & 0.9674 & 0.8164 \\
\hline Exchange rate USD/TRY & 1.7063 & 3.0305 & 1.1682 & 1.3944 & 1.3840 & 1.8587 & 0.0877 & 0.3512 \\
\hline Implied volatility (\%) & 30.274 & 32.453 & 9.1150 & 6.5065 & 16.327 & 15.184 & 4.0406 & 4.3012 \\
\hline \multicolumn{9}{|l|}{ Colombia } \\
\hline Bond spread 10Y (\%) & 6.5799 & 5.3527 & 0.9426 & 0.9568 & 2.9517 & 1.8914 & 1.3107 & 0.8027 \\
\hline Bond spread $20 Y(\%)$ & & 5.1400 & & 1.3310 & & 2.5187 & & 0.6780 \\
\hline Bond spread 30Y (\%) & 6.3961 & 5.3048 & 1.1533 & 0.8428 & 3.4375 & 1.9067 & 1.2717 & 0.7755 \\
\hline Exchange rate USD/COL & $2,904.6$ & $3,259.0$ & $1,874.2$ & $1,748.0$ & $2,410.3$ & $1,995.3$ & 261.5 & 263.4 \\
\hline Implied volatility (\%) & 24.980 & 31.600 & 7.2789 & 7.0000 & 13.648 & 15.083 & 3.3262 & 5.4264 \\
\hline \multicolumn{9}{|l|}{ Philippines } \\
\hline Bond spread 10Y (\%) & & 3.3160 & & 0.8343 & & 1.6766 & & 0.5018 \\
\hline Bond spread $15 Y(\%)$ & 5.5588 & 5.6873 & 1.4410 & 0.9749 & 3.0935 & 2.2001 & 1.2251 & 0.7913 \\
\hline Bond spread 20Y (\%) & & 2.8680 & & 0.7480 & & 1.6341 & & 0.4185 \\
\hline Exchange rate USD/PHP & 56.420 & 48.925 & 40.950 & 40.450 & 52.411 & 44.195 & 3.9561 & 1.9480 \\
\hline Implied volatility (\%) & 12.680 & 22.201 & 4.6280 & 4.1127 & 7.7496 & 7.5778 & 1.6558 & 2.4954 \\
\hline \multicolumn{9}{|l|}{ Russian Federation } \\
\hline Bond spread 15Y (\%) & 3.9306 & 7.7536 & 0.8840 & 1.4204 & 2.0109 & 3.0320 & 0.7949 & 1.1416 \\
\hline Exchange rate USD/RUB & 30.740 & 70.808 & 24.280 & 27.201 & 27.801 & 34.869 & 1.5546 & 9.1571 \\
\hline Implied volatility (\%) & 11.000 & 76.556 & 2.4000 & 8.2126 & 6.4438 & 17.489 & 1.2677 & 10.410 \\
\hline \multicolumn{9}{|l|}{ United States } \\
\hline Treasury yield 10Y (\%) & 5.2928 & 3.9859 & 3.1121 & 1.3875 & 4.4369 & 2.5855 & 0.3660 & 0.6400 \\
\hline Treasury yield 15Y (\%) & 5.3664 & 4.3478 & 3.6211 & 1.7488 & 4.6777 & 2.9555 & 0.2968 & 0.6725 \\
\hline Treasury yield 20Y (\%) & 5.6100 & 4.7500 & 4.1300 & 2.0400 & 4.9180 & 3.3237 & 0.2856 & 0.7137 \\
\hline Treasury yield 30Y (\%) & 5.5606 & 4.8395 & 4.1730 & 2.2222 & 4.8515 & 3.5645 & 0.2783 & 0.6415 \\
\hline Short term interest rate & 5.7250 & 1.4213 & 1.0000 & 0.2229 & 3.5596 & 0.3725 & 1.7198 & 0.2209 \\
\hline
\end{tabular}

$\mathrm{BRL}=$ Brazilian real, $\mathrm{COL}=$ Colombian peso, $\mathrm{MXN}=$ Mexican peso, $\mathrm{PHP}=$ Philippine peso, $\mathrm{RUB}=$ Russian ruble, $\mathrm{TRY}=$ Turkish lira, USD = US dollar.

Notes: The preglobal financial crisis period covers 1 June 2003 to 31 December 2007, while the postglobal financial crisis period is from 1 January 2009 to 29 September 2014. The tenor of the bonds in years is indicated by 10Y, 15Y, etc.

Source: Authors' compilation. 
Figure 2: Exchange Rates and Option-Implied Volatility of Emerging Market Currencies
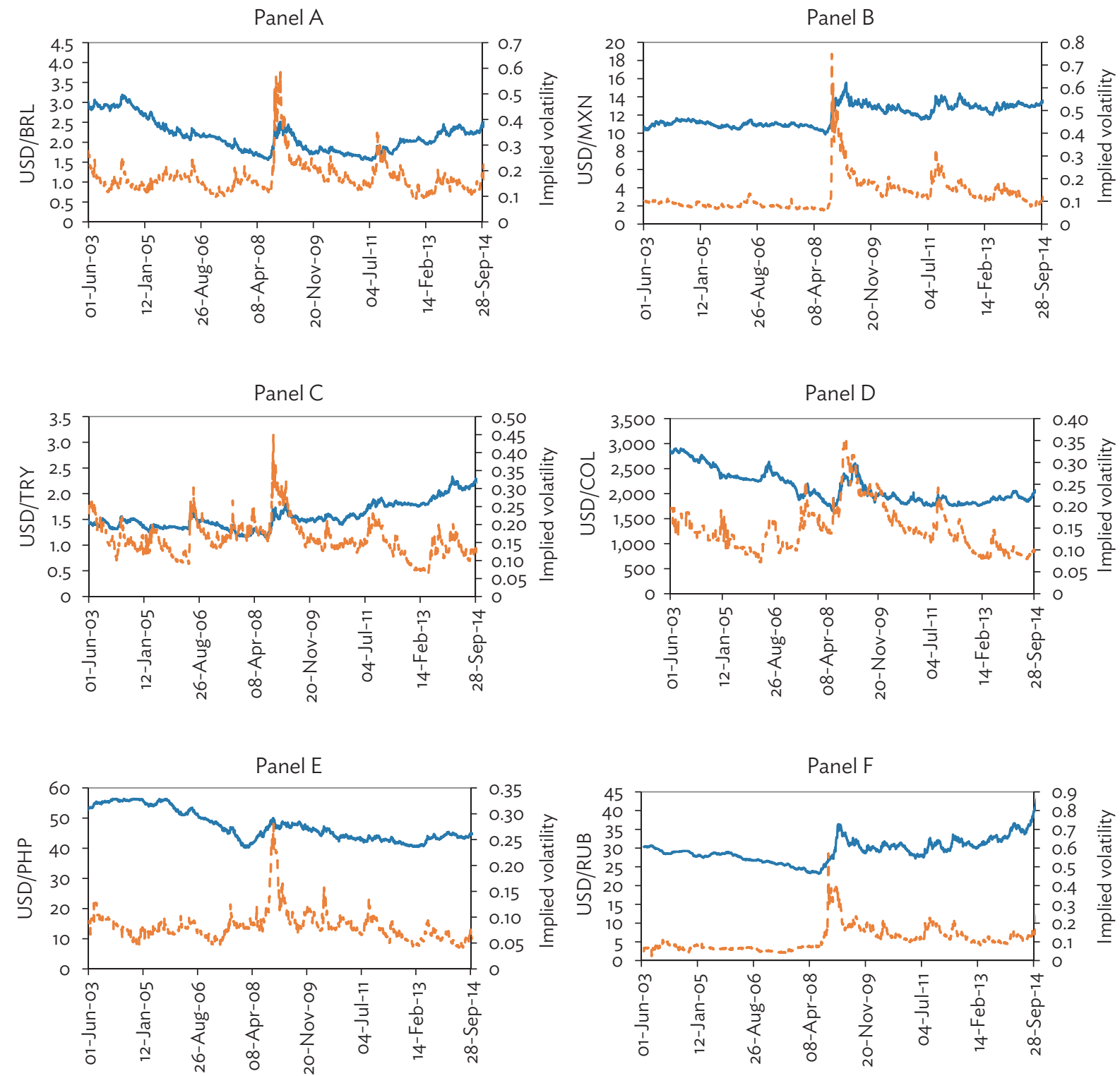

$\mathrm{BRL}=$ Brazilian real, $\mathrm{COL}=$ Colombian peso, $\mathrm{MXN}=$ Mexican peso, $\mathrm{PHP}=$ Philippine peso, $\mathrm{RUB}=$ Russian ruble, $\mathrm{TRY}=$ Turkish lira, USD = US dollar.

Source: Authors' estimates. 
Table 2: Regression Results for Daily Credit Spread Changes in Treasury Yields and Exchange Rates

\begin{tabular}{|c|c|c|c|c|c|}
\hline & $a$ & $b$ & c & Adj $R^{2}$ & $\mathrm{~N}$ \\
\hline $\begin{array}{l}\text { Brazil precrisis } \\
10 Y \\
15 Y \\
20 Y \\
30 Y \\
\end{array}$ & $\begin{array}{l}-1.79 \mathrm{E}-05 \\
-2.28 \mathrm{E}-05 \\
-2.63 \mathrm{E}-05 \\
-2.39 \mathrm{E}-05 \\
\end{array}$ & $\begin{array}{l}0.032579^{* * *} \\
0.022915^{* * *} \\
0.024404^{* * *} \\
0.026017^{* * *} \\
\end{array}$ & $\begin{array}{l}-0.423821^{* * *} \\
-0.456325^{* * *} \\
-0.434065^{* * *} \\
-0.377374^{* * *}\end{array}$ & $\begin{array}{l}0.301740 \\
0.247755 \\
0.269502 \\
0.274398 \\
\end{array}$ & $\begin{array}{l}1,069 \\
1,091 \\
1,194 \\
1,193 \\
\end{array}$ \\
\hline $\begin{array}{l}\text { Brazil postcrisis } \\
10 Y \\
15 Y \\
20 Y \\
30 Y \\
\end{array}$ & $\begin{array}{l}-1.51 E-05 \\
-1.12 E-05 \\
-1.18 E-05 \\
-163 E-05 \\
\end{array}$ & $\begin{array}{l}0.008872^{* * *} \\
0.008278^{* * *} \\
0.008134^{* * *} \\
0.009925^{* * *} \\
\end{array}$ & $\begin{array}{l}-0.759033^{* * *} \\
-0.908440^{* * *} \\
-0.795108^{* * *} \\
-0.777030^{* * *}\end{array}$ & $\begin{array}{l}0.564520 \\
0.714829 \\
0.559443 \\
0.474237 \\
\end{array}$ & $\begin{array}{r}1,365 \\
1,495 \\
1,495 \\
988 \\
\end{array}$ \\
\hline $\begin{array}{l}\text { Mexico precrisis } \\
10 Y \\
15 Y \\
20 Y \\
30 Y\end{array}$ & $\begin{array}{r}-8.88 \mathrm{E}-05 \\
-7.67 \mathrm{E}-05 \\
-1.38 \mathrm{E}-05 \\
-8.88 \mathrm{E}-06 \\
\end{array}$ & $\begin{array}{l}0.002285^{* * *} \\
0.002536^{* * *} \\
0.002025^{* * *} \\
0.002381^{* * *} \\
\end{array}$ & $\begin{array}{l}-0.388730^{* * *} \\
-0.438689^{* * *} \\
-0.351745^{* * *} \\
-0.422331^{1 * *}\end{array}$ & $\begin{array}{l}0.250256 \\
0.264938 \\
0.199819 \\
0.254845 \\
\end{array}$ & $\begin{array}{r}1,083 \\
1,148 \\
921 \\
1,193 \\
\end{array}$ \\
\hline $\begin{array}{l}\text { Mexico postcrisis } \\
10 Y \\
15 Y \\
20 Y \\
30 Y\end{array}$ & $\begin{array}{l}-1.66 \mathrm{E}-05 \\
-1.15 \mathrm{E}-05 \\
-1.16 \mathrm{E}-05 \\
-1.02 \mathrm{E}-05 \\
\end{array}$ & $\begin{array}{l}0.001129^{* * *} \\
0.000752^{* * *} \\
0.001270^{* * *} \\
0.001863^{* * *}\end{array}$ & $\begin{array}{l}-0.757392^{* * *} \\
-0.874257^{* * *} \\
-0.856517^{* * *} \\
-0.717229^{* * *}\end{array}$ & $\begin{array}{l}0.305870 \\
0.321954 \\
0.546522 \\
0.538340 \\
\end{array}$ & $\begin{array}{l}1,425 \\
1,438 \\
1,494 \\
1,493 \\
\end{array}$ \\
\hline $\begin{array}{l}\text { Turkey precrisis } \\
10 Y \\
15 Y \\
20 Y \\
30 Y\end{array}$ & $\begin{array}{l}-4.60 \mathrm{E}-05 \\
-3.04 \mathrm{E}-05 \\
-4.84 \mathrm{E}-05 \\
-2.79 \mathrm{E}-05 \\
\end{array}$ & $\begin{array}{l}0.037080^{* * *} \\
0.032201^{* * *} \\
0.020255^{* * *} \\
0.027035^{* * *} \\
\end{array}$ & $\begin{array}{l}-0.725606^{* * *} \\
-0.704508^{* * *} \\
-0.750334^{* * *} \\
-0.705168^{* * *}\end{array}$ & $\begin{array}{l}0.312478 \\
0.437636 \\
0.506729 \\
0.380692 \\
\end{array}$ & $\begin{array}{r}931 \\
1,148 \\
768 \\
1,195 \\
\end{array}$ \\
\hline $\begin{array}{l}\text { Turkey postcrisis } \\
10 Y \\
15 Y \\
20 Y \\
30 Y\end{array}$ & $\begin{array}{l}-2.88 \mathrm{E}-05 \\
-2.79 \mathrm{E}-05 \\
-2.44 \mathrm{E}-05 \\
-2.88 \mathrm{E}-05 \\
\end{array}$ & $\begin{array}{l}0.024269^{* * *} \\
0.021272^{* * *} \\
0.020266^{* * *} \\
0.019635^{* * *} \\
\end{array}$ & $\begin{array}{c}-0.988732^{* * *} \\
-1.043532^{* * *} \\
-0.999196^{* * *} \\
-1.022787^{* * *}\end{array}$ & $\begin{array}{l}0.475544 \\
0.589325 \\
0.559800 \\
0.548374 \\
\end{array}$ & $\begin{array}{l}1,494 \\
1,438 \\
1,491 \\
1,497 \\
\end{array}$ \\
\hline $\begin{array}{l}\text { Colombia precrisis } \\
10 \mathrm{Y} \\
30 \mathrm{Y}\end{array}$ & $\begin{array}{l}-2.69 \mathrm{E}-05 \\
-8.41 \mathrm{E}-06 \\
\end{array}$ & $\begin{array}{l}2.00 \mathrm{E}-05^{* * *} \\
1.78 \mathrm{E}-05^{* * *} \\
\end{array}$ & $\begin{array}{l}-0.878571^{* * *} \\
-0.671917^{* * *} \\
\end{array}$ & $\begin{array}{l}0.226331 \\
0.241309 \\
\end{array}$ & $\begin{array}{l}1,082 \\
1,192 \\
\end{array}$ \\
\hline $\begin{array}{l}\text { Colombia postcrisis } \\
10 Y \\
20 Y \\
30 Y\end{array}$ & $\begin{array}{l}-2.07 \mathrm{E}-05 \\
-1.04 \mathrm{E}-05 \\
-1.59 \mathrm{E}-05 \\
\end{array}$ & $\begin{array}{l}1.60 \mathrm{E}-05^{* * *} \\
1.04 \mathrm{E}-05^{* * *} \\
1.57 \mathrm{E}-05^{* * *} \\
\end{array}$ & $\begin{array}{l}-0.857612^{* * *} \\
-0.858695^{* * *} \\
-0.796530^{* * *}\end{array}$ & $\begin{array}{l}0.517760 \\
0.536560 \\
0.579839 \\
\end{array}$ & $\begin{array}{r}1,280 \\
1,135 \\
1,470 \\
\end{array}$ \\
\hline $\begin{array}{l}\text { Philippines precrisis } \\
15 Y\end{array}$ & $-3.16 \mathrm{E}-05$ & $0.000519^{* * *}$ & $-0.897891^{* * *}$ & 0.453476 & 761 \\
\hline $\begin{array}{l}\text { Philippines postcrisis } \\
10 Y \\
15 Y \\
20 Y\end{array}$ & $\begin{array}{l}-1.83 \mathrm{E}-05 \\
-2.46 \mathrm{E}-05 \\
-1.45 \mathrm{E}-05\end{array}$ & $\begin{array}{l}1.44 \mathrm{E}-05^{* * *} \\
0.000486^{* * *} \\
0.000621^{* * *}\end{array}$ & $\begin{array}{l}-0.973819^{* * *} \\
-0.999035^{* * *} \\
-0.964019^{* * *}\end{array}$ & $\begin{array}{l}0.528773 \\
0.652513 \\
0.601138\end{array}$ & $\begin{array}{r}919 \\
1,498 \\
1,290\end{array}$ \\
\hline $\begin{array}{l}\text { Russian Federation precrisis } \\
15 \mathrm{Y}\end{array}$ & $-5.22 \mathrm{E}-06$ & $0.001060^{* * *}$ & $-0.650849^{* * *}$ & 0.304584 & 1,128 \\
\hline $\begin{array}{l}\text { Russian Federation postcrisis } \\
15 Y\end{array}$ & $-3.96 \mathrm{E}-05$ & $0.000980^{* * *}$ & $-0.991912^{* * *}$ & 0.564024 & 1,438 \\
\hline
\end{tabular}

Notes: The preglobal financial crisis period covers 1 June 2003 to 31 December 2007, while the postglobal financial crisis period is from 1 January 2009 to 29 September 2014. The tenor of the bonds in years is indicated by 10Y, 15Y, etc. $\Delta C S_{t}=a+b \Delta I_{t}+c \Delta Y_{t}+\varepsilon_{t} . \Delta C S=$ change in credit spread. $\Delta I=$ change in exchange rate. $\Delta Y=$ change in USD Treasury bond yield. ${ }^{* *}$ denotes significance at the $1 \%$ level. Source: Authors' estimates. 
The coefficients $c$ are all statistically significant at the $1 \%$ level and indicate a negative relationship between credit spreads and US Treasury yields. This finding supports the argument that investors, in particular risk-averse ones, sell risky assets (i.e., sovereign bonds in emerging markets) and buy US Treasuries as safe-haven assets in stressed markets. The magnitude of the estimates of $c$ shows that the relation between credit spreads and US Treasury yields is economically significant. Regarding the 10-year Brazilian bond, a 100-basis point increase in the 10-year Treasury yield decreases the Brazilian bond spread by 42 basis points in the precrisis period, and by 76 basis points in the postcrisis period. Similar effects are found for the other countries' sovereign bonds. Comparing the coefficients $c$ in the two sample periods, the effects are generally stronger for the sample countries in the postcrisis period, reflecting a more important role of US Treasuries as safe-haven assets after the crisis. One explanation is that during an extended period of low interest rates and volatility caused by the accommodative monetary policies adopted by the US and other developed economies, market participants have displayed a tendency to seek higher returns by investing in securities that carry higher credit risk such as emerging market sovereign bonds. This "search for yield" behavior has caused sovereign bond spreads to be more sensitive to US Treasury yields in the postcrisis period.

The estimated coefficients on exchange rates and Treasury yields suggest high explanatory power ranging from 0.2 to 0.71 (in terms of the adjusted R-squared) for the sample sovereign bonds. This suggests that these two factors are adequate determinants of the countries' sovereign credit spreads. The empirical results support the view that the exchange rates of emerging market currencies can be used as the state variable with adequate explanatory power in a semistructural model for pricing their own US dollar-denominated sovereign bonds. Comparing the adjusted R-squared in the two sample periods, the explanatory power of exchange rates in the postcrisis period (about 0.31-0.71) is stronger than that in the precrisis period (about 0.2-0.51). This indicates that the link between sovereign credit spreads and the dynamics of the exchange rates and US interest rates has become stronger in the postcrisis period.

\section{DOLLAR-DENOMINATED SOVEREIGN BOND PRICING MODEL}

\section{A. Risk-Free Interest Rate Dynamics}

The dynamics of the US risk-free short-term interest rate $r$ in the dollar-denominated sovereign bond pricing model are drawn from the term structure model governed by the DSR process, which is introduced by Longstaff (1989): ${ }^{8}$

$$
d r=\kappa_{r}\left(\theta_{r}-\sqrt{r}\right) d t+\sigma_{r} \sqrt{r} d z_{r}
$$

where $\kappa_{r}, \sigma_{r}>0, \kappa_{r}$ is the drift parameter driving $r$ toward its mean $\theta_{r}, \sigma_{r}$ is the volatility and $\theta_{r}=\sigma_{r}^{2} / 4 \kappa_{r}>0$. Incorporating the market price of risk $\lambda_{r}$ with respect to $r$, the risk-adjusted equation (2) becomes

$$
d r=\left(\frac{\sigma_{r}^{2}}{4}-\kappa_{r} \sqrt{r}-2 \lambda_{r} r\right) d t+\sigma_{r} \sqrt{r} d z_{r}
$$

8 It is a log utility general equilibrium model. 
The drift term in equation (2) is a nonlinear restoring force which makes the dynamics of the interest rate different from those in the CIR and Vasicek models which have a linear restoring force. While the DSR model and the CIR model have a number of common empirically relevant characteristics, such as negative interest rates being precluded and having a stationary distribution, the DSR model has two particular features due to the nonlinear restoring force. ${ }^{9}$ First, only two parameters $\kappa_{r}$ and $\sigma_{r}^{2}$ are required to determine the interest rate dynamics. It is because $\theta_{r}^{2}$, which is the long-run interest rate, is a function of the other two parameters such that $\theta_{r}^{2}=\sigma_{r}^{4} / 16 \kappa_{r}^{2}$.

Second, the interest rate is sticky downward under a positive market price of risk and some conditions of a negative market price of risk, as illustrated by Longstaff (1989). ${ }^{10}$ This feature is consistent with an extraordinarily low interest rate environment when the short rate is sticky at marginally above zero. The 3-month Treasury bill yield has been persistently near zero since the global financial crisis of 2008. The first-order serial correlation of monthly changes in the yield during this period is 0.484 , as estimated by Lo and Hui (2016), reflecting that the yield is sticky and tends to be persistent at the low levels.

Without an explicit boundary condition at $r=0$, the associated risk-free bond price function $\Phi(r, \tau)$ with time to maturity $\tau$ is given by Longstaff (1989): ${ }^{11}$

$$
\Phi(r, \tau)=A(\tau) \exp \{C(\tau) \sqrt{r}+B(\tau) r\}
$$

where

$$
\begin{gathered}
A(\tau)=\sqrt{\frac{1-C_{0}}{1-C_{0} \exp \{\gamma \tau\}} \exp \left(\alpha_{1}+\alpha_{2} \tau+\frac{\alpha_{3}+\alpha_{4} \exp \left\{\frac{1}{2} \gamma \tau\right\}}{1-C_{0} \exp \{\gamma \tau\}}\right)} \\
B(\tau)=\frac{2 \lambda_{r}-\gamma}{\sigma_{r}^{2}}+\frac{2 \gamma}{\sigma_{r}^{2}\left[1-C_{0} \exp \{\gamma \tau\}\right]} \\
C(\tau)=\frac{2 \kappa_{r}\left(2 \lambda_{r}+\gamma\right)\left(1-\exp \left\{\frac{1}{2} \gamma \tau\right\}\right)^{2}}{\gamma \sigma_{r}^{2}\left[1-C_{0} \exp \{\gamma \tau\}\right]}
\end{gathered}
$$

9 The other two common characteristics include: (i) the interest rate returns to positive values if it approaches zero, and (ii) the instantaneous variance $\sigma_{r}^{2} r$ is directly related to the interest rate. More detailed analyses and empirical evidence of stochastic interest rates following the DSR process, and the boundary behavior of the process are in Longstaff (1989) and (1992), and Karlin and Taylor (1981, chapter 15).

10 Also see Appendix A in Lo and Hui (2016) for a discussion of the properties of the DSR model.

11 This is analogous to the unrestricted equilibrium discussed in section 3 of Longstaff (1992). Beaglehole and Tenney (1992) point out that Longstaff's (1989) bond pricing equation is not the solution for a reflecting boundary condition. 
with

$$
\begin{gathered}
\gamma=\sqrt{4 \lambda_{r}^{2}+2 \sigma_{r}^{2}} \quad, \quad C_{0}=\frac{2 \lambda_{r}+\gamma}{2 \lambda_{r}-\gamma} \\
\alpha_{1}=-\frac{\kappa_{r}^{2}}{\gamma^{3} \sigma_{r}^{2}}\left(4 \lambda_{r}+\gamma\right)\left(2 \lambda_{r}-\gamma\right) \quad, \quad \alpha_{2}=\frac{2 \lambda_{r}+\gamma}{4}-\frac{\kappa_{r}^{2}}{\gamma^{2}} \\
\alpha_{3}=\frac{4 \kappa_{r}^{2}}{\gamma^{3} \sigma_{r}^{2}}\left(2 \lambda_{r}^{2}-\sigma_{r}^{2}\right) \quad, \quad \alpha_{4}=-\frac{8 \kappa_{r}^{2} \lambda_{r}}{\gamma^{3} \sigma_{r}^{2}}\left(2 \lambda_{r}+\gamma\right)
\end{gathered}
$$

\section{B. Valuation of United States Dollar-Denominated Sovereign Bonds}

The valuation of US dollar-denominated sovereign bonds assumes a semistructural framework, and the exchange rate is a stochastic variable. The risk-adjusted dynamic of the exchange rate $S$, which determines the probability of default of a sovereign bond, is assumed to follow a lognormal diffusion process, which is commonly used for pricing exchange rate options and derivatives. Its continuous stochastic movement is modeled by the following stochastic differential equation:

$$
\frac{d S}{S}=\alpha_{S} d t+\sigma_{S} d z_{S}
$$

where $\sigma_{S}$ is the volatility, $\alpha_{S}$ is the drift rate, and $d z_{S}$ denotes a standard Wiener process.

Using the DSR model of the risk-free interest rate in the pricing framework, the Wiener processes $d z_{r}$ and $d z_{S}$ in equations (3) and (8) are correlated with:

$$
d z_{S} d z_{r}=\rho_{S r} d t
$$

Ito's lemma is then applied to derive the partial differential equation governing a sovereign discount bond $P(S, r, \tau)$ with the time to maturity of $\tau$ as follows:

$$
\begin{aligned}
\frac{\partial P}{\partial \tau} & =\frac{1}{2} \sigma_{S}^{2} S^{2} \frac{\partial^{2} P}{\partial S^{2}}+\rho_{S r} \sigma_{S} \sigma_{r} S \sqrt{r} \frac{\partial^{2} P}{\partial r \partial S}+\frac{1}{2} \sigma_{r}^{2} r \frac{\partial^{2} P}{\partial r^{2}}+\alpha S \frac{\partial P}{\partial S} \\
& +\left(\frac{1}{4} \sigma_{r}^{2}-\kappa_{r} \sqrt{r}-2 \lambda_{r} r\right) \frac{\partial P}{\partial r}-r P
\end{aligned}
$$

In terms of the new variables and parameters:

$$
\begin{gathered}
x=\sqrt{2 r} \quad, \quad y=\ln \left(\frac{S}{S_{0}}\right) \quad, \quad y_{0}=\ln S_{0} \quad, \quad \tilde{\sigma}_{r}=\frac{\sigma_{r}}{\sqrt{2}} \\
\widetilde{\kappa}_{r}=\frac{\kappa_{r}}{\sqrt{2}}, \quad \widetilde{\alpha}=\alpha-\frac{\alpha^{2}}{2}
\end{gathered}
$$


Equation (10) becomes:

$$
\begin{aligned}
\frac{\partial P}{\partial \tau} & =\frac{1}{2} \sigma_{S}^{2} \frac{\partial^{2} P}{\partial y^{2}}+\rho_{S r} \sigma_{L} \tilde{\sigma}_{r} \frac{\partial^{2} P}{\partial x \partial y}+\frac{1}{2} \tilde{\sigma}_{r}^{2} \frac{\partial^{2} P}{\partial x^{2}}+\tilde{\alpha} \frac{\partial P}{\partial y} \\
& -\left(\tilde{\kappa}_{r}+\lambda_{r} x\right) \frac{\partial P}{\partial x}-\frac{1}{2} x^{2} P
\end{aligned}
$$

Without loss of generality, $P(x, y, \tau)$ is assumed to be of the product form: $P(x, y, \tau)=\Phi(x, \tau) \tilde{P}(x, y, \tau)$, where the unknown function $\tilde{P}(x, y, \tau)$ denotes the discount factor of the risk-free bond price function $\Phi(x, \tau)$ due to the possibility of default.

Under a scenario in which default can only occur at maturity and the recovery rate is $R$ at default, the final payoff condition of the bond with the face value of 1 is:

$$
\begin{aligned}
& P(S, r, 0)=1 \text { if } S \leq S_{0} \\
& P(S, r, 0)=R \text { if } S>S_{0}
\end{aligned}
$$

where $S_{0}$ is the default-triggering level above which default occurs and bondholders receive an exogenously given number of default-free bonds. Using the derivation in the Appendix, the integral in equation (A.5) can be straightforwardly evaluated to give the bond price solution:

$$
\begin{aligned}
P(x, y, \tau)= & \Phi(x, \tau) \widetilde{P}(x, y, \tau) \\
= & \frac{\Phi(x, \tau)}{\sqrt{2 \pi \Delta(\tau)}} \int_{-\infty}^{0} \exp \left\{-\frac{\left[Y(x, y, \tau)-y^{\prime}\right]^{2}}{2 \Delta(\tau)}\right\} d y+ \\
& \frac{R \Phi(x, \tau)}{\sqrt{2 \pi \Delta(\tau)}} \int_{0}^{\infty} \exp \left\{-\frac{\left[Y(x, y, \tau)-y^{\prime}\right]^{2}}{2 \Delta(\tau)}\right\} d y \\
& =\Phi(x, \tau)\left\{(1-R) N\left(-\frac{Y(x, y, \tau)}{\sqrt{\Delta(\tau)}}\right)+R\right\}
\end{aligned}
$$

where N(.) denotes the cumulative distribution function of a standard normal distribution. The discount factor of the sovereign bond price can be identified as the measure of default probability associated with the exchange rate $S$; that is, $P_{d e f}(S, r, \tau)=1-\tilde{P}(x, y, \tau)$.

To allow default before maturity, a fixed or constant absorbing boundary (default barrier) is incorporated into the pricing model. Regarding pricing corporate bonds, Black and Cox (1976) assume a default-triggering level for the firm's assets whereby default can occur at any time. This trigger level is introduced by considering a safety covenant that protects bondholders. However, in the absence of a supranational legal authority to enforce any safety covenant, a country may have more discretion whether to pay its debt obligations in the case of default. ${ }^{2}$ Given such sovereign immunity, currency

12 Discussions on sovereign immunity and debt crisis can be found in Eaton (1996) and Kletzer and Wright (2000). 
depreciation is assumed to be the only factor a country will consider in deciding whether to meet its obligations on US dollar-denominated bonds.

When the exchange rate devalues and breaches a predefined level, default occurs before maturity and the issuer (government) is unable to repay its sovereign foreign currency debt. However, with a constant default barrier, no closed-form pricing solution is available. On the other hand, the method of images can derive the closed-form pricing solution $\widetilde{P}(x, y, \tau)$, which has a moving absorbing boundary specified by $y=\left\{\chi \Delta(\tau)-\Omega_{2}(\tau)-\omega(\tau) \exp [\varsigma(\tau)] x\right\}$ for some adjustable real parameter $\chi$ as follows:

$$
\begin{aligned}
\widetilde{P}(x, y, \tau)= & \frac{1}{\sqrt{2 \pi \Delta(\tau)}} \int_{-\infty}^{0}\left[\exp \left\{-\frac{\left[Y(x, y, \tau)-y^{\prime}\right]^{2}}{2 \Delta(\tau)}\right\}-\right. \\
& \left.\exp \left(2 \chi y^{\prime}\right) \exp \left\{-\frac{\left[Y(x, y, \tau)+y^{\prime}\right]^{2}}{2 \Delta(\tau)}\right\}\right] f\left(y^{\prime}\right) d y^{\prime}
\end{aligned}
$$

Since $f(y)$ is equal to unity, the integral can be straightforwardly evaluated to give:

$$
\begin{aligned}
\widetilde{P}(x, y, \tau)= & N\left(-\frac{Y(x, y, \tau)}{\sqrt{\Delta(\tau)}}\right)-N\left(\frac{Y(x, y, \tau)}{\sqrt{\Delta(\tau)}}-2 \chi \sqrt{\Delta(\tau)}\right) \times \\
& \exp \left[-2 \chi Y(x, y, \tau)+2 \chi^{2} \Delta(\tau)\right]
\end{aligned}
$$

The sovereign bond price with default allowed before bond maturity and a recovery rate of $R$ is:

$$
P(S, r, \tau)=\Phi(x, \tau) \widetilde{P}(x, y, \tau)+R(1-\widetilde{P}(x, y, \tau)) \Phi(x, \tau)
$$

As the movement of the absorbing boundary is adjustable by tuning the parameter $\chi$, the default barrier can thus be adjusted such that the solution in equation (16) provides a good approximation to the exact result for a constant default barrier by using the methodology developed in Lo, Lee, and Hui (2003) for solving barrier option values with time-dependent model parameters. In addition, such a dynamic default barrier is flexible enough to incorporate different default scenarios, as demonstrated in Hui, Lo, and Tsang (2003). For example, default could be triggered even though the exchange rate is below $S_{0}$ because of the liquidity problem (such as repayments of short-term debts) faced by the government. In this case, a default scenario of higher short-term default probability can be incorporated into the valuation model by adjusting the default barrier lower than $S_{0}$ in the early period (say 1 to 2 years) of the time to maturity of the bond.

\section{MARKET AND MODEL-IMPLIED SOVEREIGN BOND CREDIT SPREADS}

\section{A. Parameters for Pricing Bonds}

Using the sovereign bond pricing model developed in the previous section, corresponding daily modelimplied bond prices are obtained for: Brazil, Mexico, and Turkey (with 10-year, 15-year, 20-year, and 30- 
year tenors); Colombia (with 10-year and 30-year tenors); the Philippines (with 10-year, 15-year, and 20-year tenors); and the Russian Federation (with a 15-year tenor) in the precrisis and postcrisis periods. The model-implied credit spread $C_{S}$ of a sovereign discount bond price $P(S, r, \tau)$ with a default barrier (default allowed before bond maturity) based on equation (16) is given as:

$$
C_{S}(S, r, \tau)=-\frac{1}{\tau} \ln \left(\frac{P(S, r, \tau)}{\Phi(r, \tau)}\right)=-\frac{1}{\tau} \ln (\widetilde{P}(x, y, \tau))
$$

The input parameters for the model are $\alpha_{s}$ and $\sigma_{s}$ for the exchange rate $S$ and $\kappa_{r}, \sigma_{r}$, and $\lambda_{r}$ for the US dollar interest rate $r$. To make the pricing framework simple for analyzing the performance of the model, the drift $\alpha_{s}$ is assumed to be zero. ${ }^{13}$ Given that the bond pricing model needs to capture forwardlooking market information and currency crash risk, which affect credit spreads, use the 3-month currency option-implied volatility of the 25-delta out-of-the-money call (US dollar) for volatility $\sigma_{s}$, illustrated in Figure $2 .{ }^{14}$ While the option-implied volatilities of the currencies surged during the crisis in 2008, as expected, they also varied substantially during other times, in particular in the postcrisis period. The sensitivity of dollar-denominated sovereign bond spreads to exchange rate risk anticipated by market participants is incorporated into the model through the parameter of the exchange rate volatility. Currency option markets have the desirable property of being forward looking in nature and are thus useful for gauging market sentiment about future exchange rates. Market sentiment of the "crash risk" of a currency can be inferred from its out-of-the-money option-implied volatility, which is consistent with a number of recent studies on currency crashes using information on currency option prices, including Brunnermeier, Nagel, and Pedersen (2009); Farhi et al. (2009); and Hui and Chung (2011). ${ }^{15}$

For the interest rate, $r$ is the daily US dollar 3-month Treasury yield. The values of the model parameters $\kappa_{r}, \sigma_{r}$, and $\lambda_{r}$ of the DSR interest rate model are shown in Table 3. The DSR model parameters are estimated by using Hansen's (1982) generalized method of moments technique which is also used by Longstaff (1989) for the estimation of the DSR term structure model. ${ }^{16}$ The estimations are using month-end zero-coupon yield to maturity data of 3-month, 12-month and 10-year US Treasury bills and notes during January 2000 to September 2014 . The daily correlation $\rho_{S_{r}}$ is estimated by the dynamic conditional correlation multivariate GARCH model proposed by Engle and Sheppard (2001). The recovery rate $R$ is 0.25 for Brazil, Turkey, Mexico, Colombia, and the Russian Federation, and 0.4 for the Philippines. ${ }^{17}$

13 The expected future exchange rate can be incorporated into the model by specifying a drift for the exchange rate dynamics. For example, assuming that uncovered interest rate parity holds, the drift is the interest rate differential between an emerging market currency and the US dollar.

14 The Black-Scholes delta provides a normalized measure of option "moneyness" where the delta of a European option increases monotonically from 0 to 100, with the "moneyness" moving from out-of-the-money to in-the-money.

15 Gray, Merton, and Bodie (2007) use exchange rate volatility as a fundamental factor associated with the dynamics of an economy's asset, which is the underlying variable estimated from the public balance sheet, in their contingent claims analysis to price sovereign credit risk.

16 Both the estimations in Table 3 and Longstaff (1989) have large standard errors which are primarily due to the high correlations among the individual parameters.

17 The data of option-implied volatility are from JP Morgan. The recovery rates are from Bloomberg. 
Table 3: Generalized Method of Moments Estimates of the DSR Model

\begin{tabular}{llll}
\hline Parameters & $\kappa_{r}$ & $\sigma_{r}^{2}$ & $\lambda_{r}$ \\
\hline Point estimate & 0.0176 & 0.0072 & -0.0686 \\
Standard errors & 0.0073 & 0.0003 & 0.00276 \\
\hline
\end{tabular}

DSR = double square root.

Notes: The table uses month-end zero-coupon yield to maturity data of 3-month, 12-month, and 10-year US Treasury bills and notes from January 2000 to September 2014. Data are from the US Federal Reserve. The standard errors are computed by the Newey and West (1987) heteroskedasticity and autocorrelation-consistent estimate of the covariance matrix of the yields.

Source: Authors' estimates.

Two simple methods are used to set the barriers to test the proposed model, given that default barriers are not observable. The first method is to set the barriers at the highest exchange rates during the full period, i.e., the lowest values of the currencies against the US dollar, which are denoted as reference default barriers. The second method is to calibrate the barriers (denoted as calibrated default barriers) by minimizing the differences between the market and model-implied credit spreads. The levels of default barriers based on these two methods in the precrisis and postcrisis periods for the pricing of the corresponding sovereign bonds are in Table 4.

Table 4: Levels of Default Barriers, Precrisis and Postcrisis

\begin{tabular}{|c|c|c|c|c|}
\hline & \multicolumn{2}{|c|}{ Precrisis Period } & \multicolumn{2}{|c|}{ Postcrisis Period } \\
\hline & Calibrated Barrier & Reference Barrier & Calibrated Barrier & Reference Barrier \\
\hline \multicolumn{5}{|l|}{ Brazil } \\
\hline $10 Y$ & 3.64 & 3.2 & 3.68 & 3.2 \\
\hline $15 Y$ & 3.31 & 3.2 & 3.64 & 3.2 \\
\hline $20 Y$ & 3.11 & 3.2 & 3.17 & 3.2 \\
\hline $30 Y$ & 2.77 & 3.2 & 2.91 & 3.2 \\
\hline \multicolumn{5}{|l|}{ Mexico } \\
\hline $10 Y$ & 15.7 & 16 & 23.7 & 16 \\
\hline $15 Y$ & 15.2 & 16 & 22.6 & 16 \\
\hline $20 Y$ & 14.94 & 16 & 20.4 & 16 \\
\hline $30 Y$ & 13.77 & 16 & 18.7 & 16 \\
\hline \multicolumn{5}{|l|}{ Turkey } \\
\hline $10 Y$ & 2.1 & 1.86 & 2.86 & $1.86 /$ change \\
\hline $15 Y$ & 1.89 & 1.86 & 2.61 & $1.86 /$ change \\
\hline $20 Y$ & 1.93 & 1.86 & 2.52 & $1.86 /$ change \\
\hline $30 Y$ & 1.6 & 1.86 & 2.29 & $1.86 /$ change \\
\hline \multicolumn{5}{|l|}{ Colombia } \\
\hline $10 Y$ & 3400 & 2900 & 3410 & 2900 \\
\hline $20 Y$ & & & 2650 & 2900 \\
\hline $30 Y$ & 2690 & 2900 & 2600 & 2900 \\
\hline \multicolumn{5}{|l|}{ Philippines } \\
\hline $10 Y$ & & & 53.7 & 57 \\
\hline $15 Y$ & 58 & 57 & 53.3 & 57 \\
\hline $20 Y$ & & & 53.3 & 57 \\
\hline \multicolumn{5}{|l|}{ Russian Federation } \\
\hline $15 Y$ & 35.1 & 31 & 44.1 & 40 \\
\hline
\end{tabular}

Notes: The preglobal financial crisis period covers 1 June 2003 to 31 December 2007, while the postglobal financial crisis period is from 1 January 2009 to 29 September 2014. The tenor of the bonds in years is indicated by 10Y, 15Y, etc. For Turkey, 1.86/change denotes that the reference barrier is at the level of 1.86 but changes during the sample period as the exchange rate exceeds 1.86 .

Source: Authors' estimates. 


\section{B. Predicted Spreads from the Model}

The model and market credit spreads of the sovereign bonds of Brazil, Mexico, Turkey, the Philippines, and the Russian Federation with a tenor of 15 years; and Colombia with the tenor of 10 years are illustrated in Figure 3.

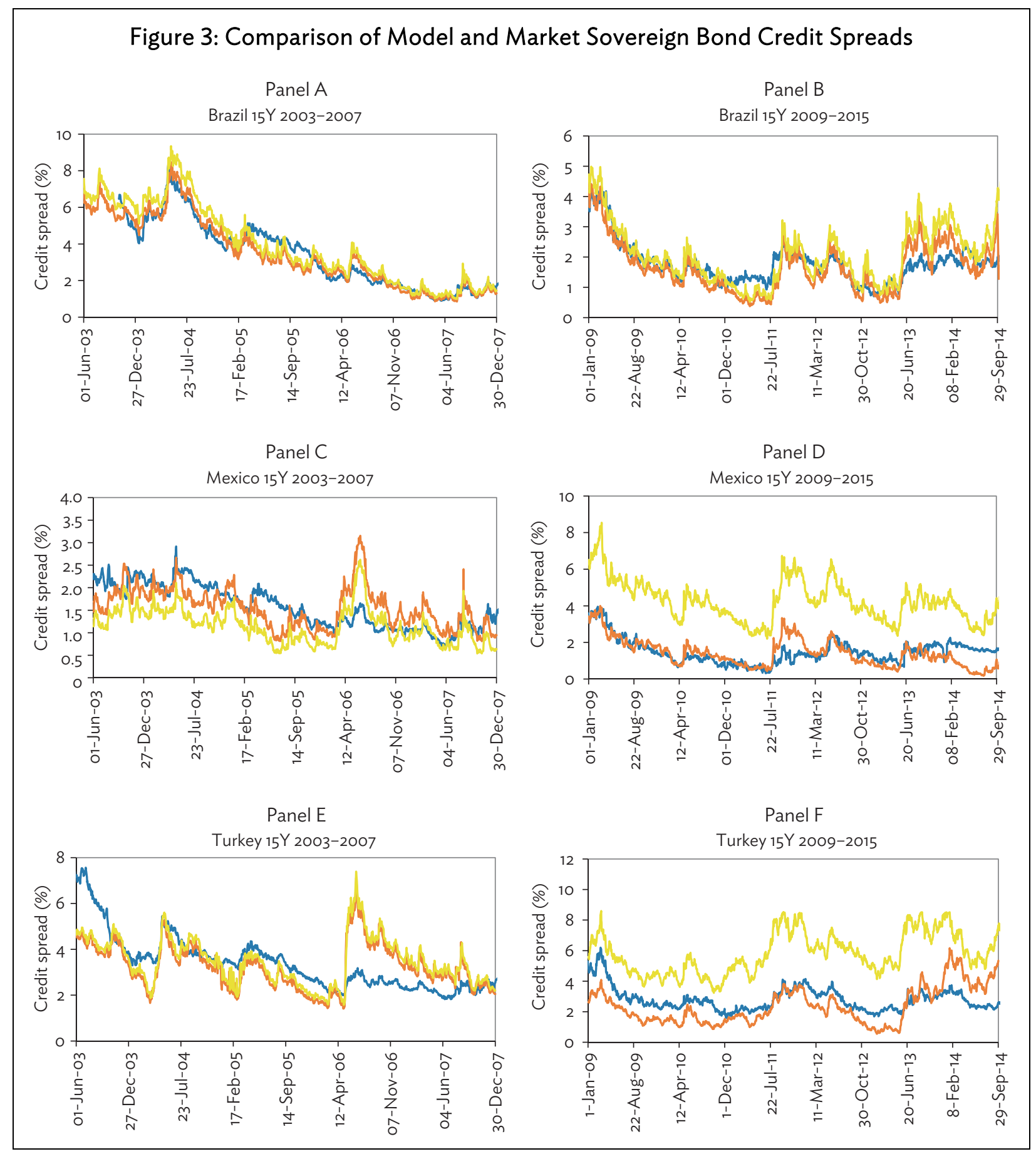

continued on next page 
Figure 3 continued

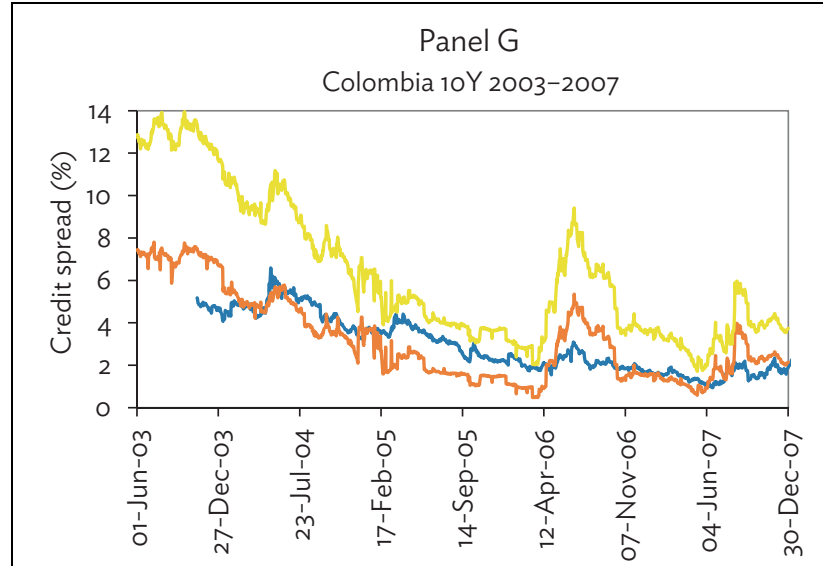

Panel I

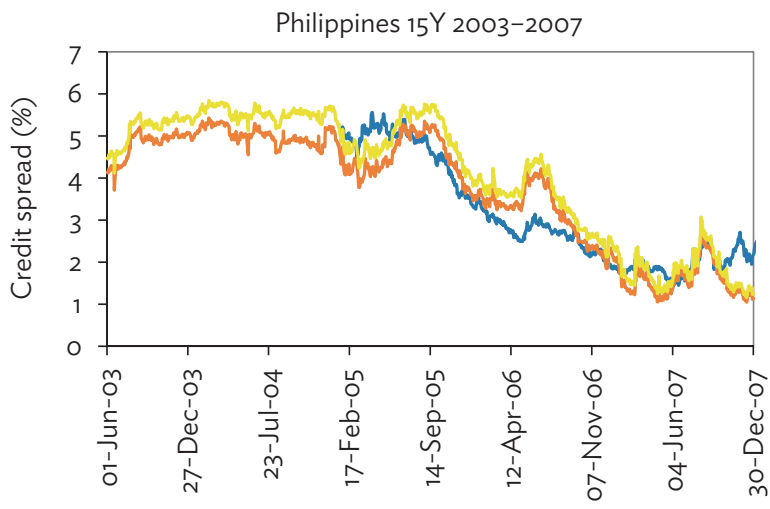

Panel K

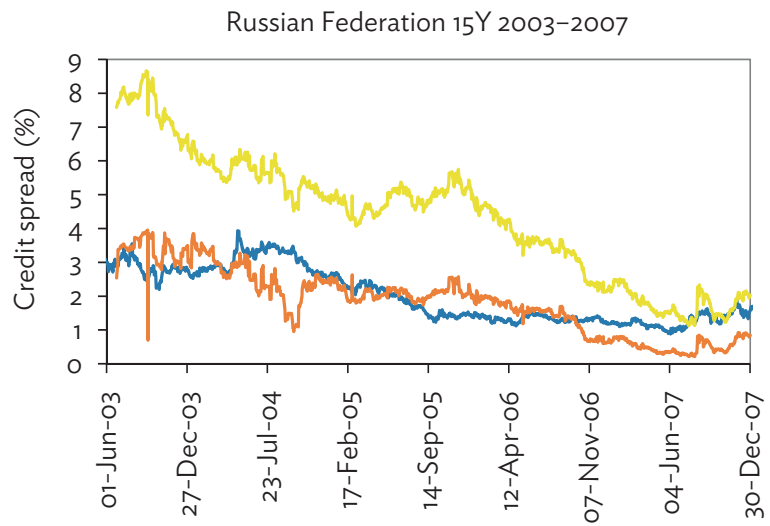

Panel H

Colombia 10Y 2009-2015

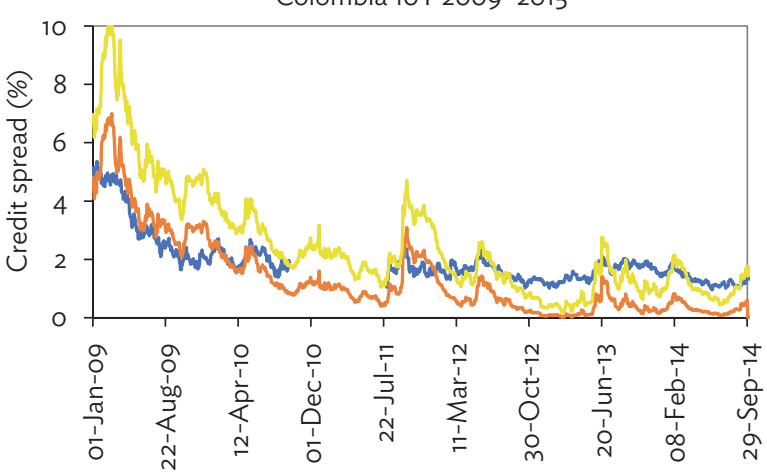

Panel J

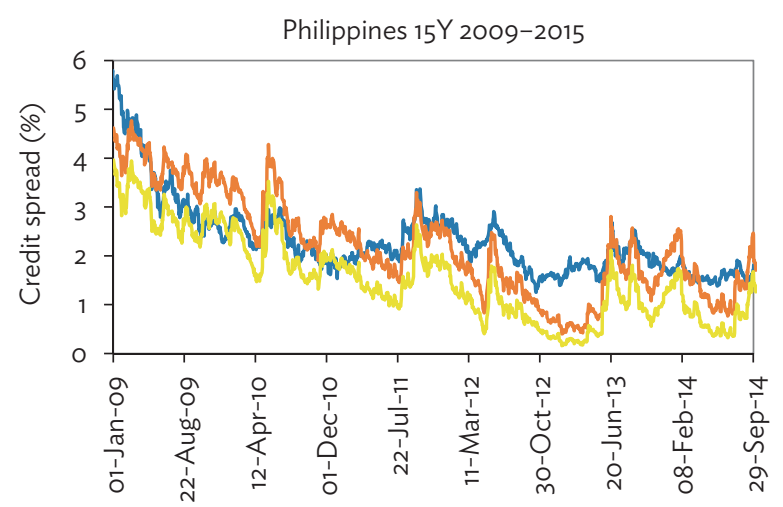

Panel L

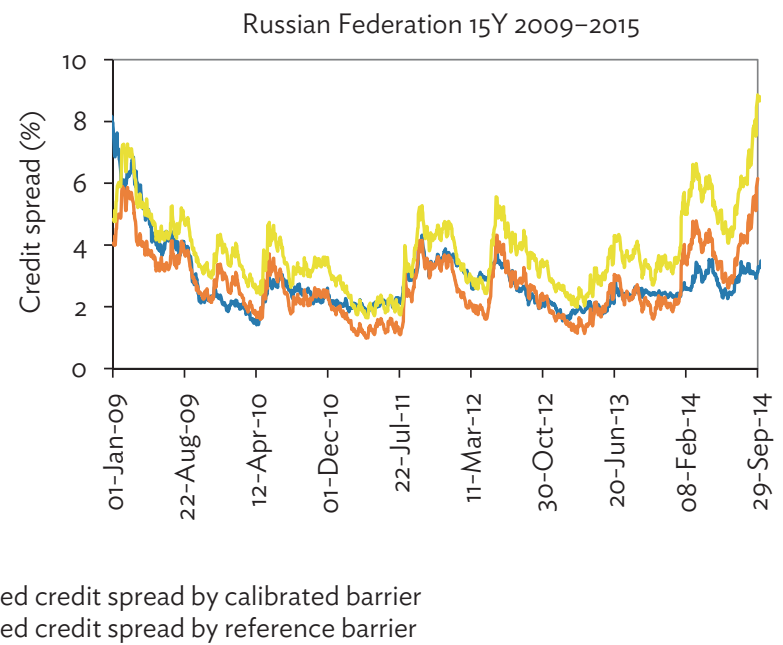

Source: Authors' estimates. 
The results in Panels $A$ and $B$ show that the model credit spreads based on the calibrated and reference default barriers of the Brazilian sovereign bond track the market credit spreads closely, particularly during 2007 before the global financial crisis and in 2009-2010 after the crisis. Given that the calibrated barriers are higher than the reference barrier, the model credit spreads obtained from the calibrated barriers are lower than those obtained from the reference barrier and closer to the market credit spreads as expected. The trend in the model credit spreads generated from the different default barriers are qualitatively similar, indicating that the default barriers affect mainly the level of the spreads. Correlations between the market and model credit spreads of the bonds with different tenors are reported in Table 5. The high positive correlations in level (higher than 0.8) and in log change (between 0.3 and 0.54 ) are consistent with the observations in Panels A and B of Figure 3.

Regarding the Mexican sovereign bond in Panel $\mathrm{C}$, the model credit spreads based on the calibrated and reference default barriers have similar trends in the market credit spreads in the precrisis period. For example, both the market and model spreads jumped in mid-2006 and mid-2007. The correlations between their spreads at different tenors are above 0.4 in level and 0.28 in log change. During the postcrisis period, as shown in Panel C, the model credit spreads generated from the calibrated barriers are quite close to the market credit spreads with the correlations for different tenors above 0.65 in level and 0.21 in log change.

While the model credit spreads based on the reference barrier are higher than the market values, their changes broadly follow those of the market and model (based on the calibrated barrier) credit spreads, as indicated by the high positive correlations in level and log change. The results demonstrate that the calibrated and reference default barriers determine the levels of the bond spreads but in general do not affect their changes substantially.

Panel $E$ in Figure 3 shows that the market and model spreads of the 15-year Turkish sovereign bond are quite close to each other during 2004 and 2005 but substantially different in 2003 and 2006. Therefore, their correlations shown in Table 5 are lower than those of the Brazilian and Mexican sovereign bonds in the precrisis period. Similar to the Mexican sovereign bond, the model spreads with the reference barrier are higher than the market spreads and model spreads with the calibrated barriers in the postcrisis period (see Panel F). Regarding the 10-year Colombian sovereign bond in Panels $G$ and $\mathrm{H}$, the model spreads with the calibrated barriers broadly track the market spreads in particular in the postcrisis period with high correlations in levels.

The tracking performance of the model spreads with the reference barrier is also better in the postcrisis period. The model spreads of the 15-year Philippine sovereign bond shown in Panels I and J exhibit similar movements of the market spreads with quite high positive correlations among the bonds with different tenors. Panel K shows that the model spreads of the 15-year Russian sovereign bond do not fit the market spreads well in the precrisis period. The tracking performance however improves significantly in the postcrisis period as shown in Panel L, and the correlations between the model and market spreads increase accordingly.

In summary, the comparison between the market and model credit spreads of the sovereign bonds of Brazil, Mexico, Turkey, Colombia, the Philippines, and the Russian Federation (as illustrated in Figure 3 and their correlations in Table 5) show that the proposed model can generate credit spreads which track the changes of the market credit spreads. The results are consistent with the regression results in section II that exchange rates in the emerging markets are related to their sovereign credit spreads. The calibrated and reference default barriers used in the model mainly shift the levels of model spreads but do not make their changes different materially. 
Table 5: Correlations between Market and Model Credit Spreads, Precrisis and Postcrisis

\begin{tabular}{|c|c|c|c|c|c|c|c|c|}
\hline & \multicolumn{4}{|c|}{ Precrisis Period } & \multicolumn{4}{|c|}{ Postcrisis Period } \\
\hline & \multicolumn{2}{|c|}{ Calibrated Barrier } & \multicolumn{2}{|c|}{ Reference Barrier } & \multicolumn{2}{|c|}{ Calibrated Barrier } & \multicolumn{2}{|c|}{ Reference Barrier } \\
\hline & Level & $\begin{array}{c}\text { Log } \\
\text { Change }\end{array}$ & Level & $\begin{array}{c}\text { Log } \\
\text { Change }\end{array}$ & Level & $\begin{array}{c}\text { Log } \\
\text { Change }\end{array}$ & Level & $\begin{array}{c}\text { Log } \\
\text { Change }\end{array}$ \\
\hline \multicolumn{9}{|c|}{ Brazil } \\
\hline $10 Y$ & 0.959539 & 0.523275 & 0.959598 & 0.520982 & 0.908860 & 0.379767 & 0.868848 & 0.397125 \\
\hline $15 Y$ & 0.953949 & 0.482760 & 0.952600 & 0.487191 & 0.830241 & 0.303421 & 0.800445 & 0.309539 \\
\hline $20 Y$ & 0.921730 & 0.508187 & 0.926139 & 0.501518 & 0.893335 & 0.320706 & 0.901480 & 0.316430 \\
\hline $30 Y$ & 0.882142 & 0.536708 & 0.899338 & 0.514740 & 0.847727 & 0.390204 & 0.871172 & 0.384474 \\
\hline \multicolumn{9}{|c|}{ Mexico } \\
\hline $10 Y$ & 0.552880 & 0.438373 & 0.549319 & 0.437605 & 0.847623 & 0.199990 & 0.799435 & 0.234820 \\
\hline $15 Y$ & 0.527560 & 0.326232 & 0.511315 & 0.325294 & 0.650370 & 0.210405 & 0.721163 & 0.240200 \\
\hline $20 Y$ & 0.418776 & 0.275607 & 0.397264 & 0.275836 & 0.785107 & 0.341452 & 0.785477 & 0.374332 \\
\hline $30 Y$ & 0.504708 & 0.350846 & 0.489280 & 0.359946 & 0.747097 & 0.427725 & 0.746418 & 0.457096 \\
\hline \multicolumn{9}{|c|}{ Turkey } \\
\hline $10 Y$ & 0.514546 & 0.089379 & 0.483176 & 0.129808 & 0.521127 & 0.140926 & 0.482898 & 0.318999 \\
\hline $15 Y$ & 0.418965 & 0.424573 & 0.419699 & 0.272989 & 0.507177 & 0.234234 & 0.568609 & 0.372451 \\
\hline $20 Y$ & 0.277704 & 0.426114 & 0.284289 & 0.243198 & 0.546733 & 0.259238 & 0.645104 & 0.374980 \\
\hline $30 Y$ & 0.371978 & 0.443446 & 0.443260 & 0.256475 & 0.269549 & 0.301469 & 0.405902 & 0.352574 \\
\hline \multicolumn{9}{|c|}{ Colombia } \\
\hline $10 Y$ & 0.749448 & 0.108970 & 0.820612 & 0.163759 & 0.905720 & 0.208497 & 0.90707 & 0.237631 \\
\hline $20 Y$ & & & & & 0.862308 & 0.216809 & 0.842845 & 0.202812 \\
\hline $30 Y$ & 0.680392 & 0.285348 & 0.643841 & 0.217847 & 0.908509 & 0.298449 & 0.887793 & 0.267469 \\
\hline \multicolumn{9}{|c|}{ Philippines } \\
\hline $10 Y$ & & & & & 0.733676 & 0.225239 & 0.756206 & 0.217695 \\
\hline $15 Y$ & 0.892079 & 0.266252 & 0.897575 & 0.272526 & 0.807720 & 0.224934 & 0.829884 & 0.211198 \\
\hline $20 Y$ & & & & & 0.748286 & 0.244271 & 0.767511 & 0.228892 \\
\hline \multicolumn{9}{|c|}{ Russian Federation } \\
\hline $15 Y$ & 0.735777 & 0.03452 & 0.762646 & 0.072708 & 0.772496 & 0.588978 & 0.696061 & 0.579182 \\
\hline
\end{tabular}

Notes: The preglobal financial crisis period covers 1 June 2003 to 31 December 2007, while the postglobal financial crisis period is from 1 January 2009 to 29 September 2014. The tenor of the bonds in years is indicated by 10Y, 15Y, etc. Log change is $\ln (C S t / C S t-1)$.

Source: Authors' estimates.

\section{Error Analysis}

Table 6 summarizes the pricing errors of the model in terms of credit spreads. There are three error measures including: (i) root-mean-square errors (RMS) in basis points (bps), (ii) percentage errors, and (iii) absolute percentage errors. The percentage errors, as well as their absolute values, are calculated as the predicated (model) spread minus the market spread divided by the market spread. Their means are reported and the numbers in parentheses are the standard deviation of the errors. 
Table 6: Performances of the Model, Precrisis and Postcrisis

\begin{tabular}{|c|c|c|c|c|c|c|}
\hline & \multicolumn{3}{|c|}{ Precrisis Period } & \multicolumn{3}{|c|}{ Postcrisis Period } \\
\hline & \begin{tabular}{|c|} 
RMS Error \\
(basis points)
\end{tabular} & Percentage Error & \begin{tabular}{|c|} 
Absolute \\
Percentage Error
\end{tabular} & $\begin{array}{c}\text { RMS Error } \\
\text { (basis points) }\end{array}$ & Percentage Error & $\begin{array}{c}\text { Absolute } \\
\text { Percentage Error }\end{array}$ \\
\hline Brazil & & $\begin{array}{c}\text { (Reference } \\
\text { barrier) }\end{array}$ & & & $\begin{array}{c}\text { (Reference } \\
\text { barrier) }\end{array}$ & \\
\hline$\overline{10 Y}$ & 263.43 & $\begin{array}{c}48.47 \\
(49.75)\end{array}$ & $\begin{array}{c}34.63 \\
(32.76)\end{array}$ & 115.78 & $\begin{array}{c}14.92 \\
(31.94)\end{array}$ & $\begin{array}{c}28.67 \\
(20.52)\end{array}$ \\
\hline $15 Y$ & 72.03 & $\begin{array}{l}10.34 \\
(17.53)\end{array}$ & $\begin{array}{c}17.69 \\
(10.06)\end{array}$ & 61.7 & $\begin{array}{c}14.74 \\
(33.75)\end{array}$ & $\begin{array}{c}27.03 \\
(25.01)\end{array}$ \\
\hline $20 Y$ & 78.95 & $\begin{array}{l}-6.596 \\
(15.62)\end{array}$ & $\begin{array}{c}13.37 \\
(10.43)\end{array}$ & 32.33 & $\begin{array}{r}7.099 \\
(25.78)\end{array}$ & $\begin{array}{l}22.45 \\
(14.52)\end{array}$ \\
\hline $30 Y$ & 164.57 & $\begin{array}{l}-33.67 \\
(10.81)\end{array}$ & $\begin{array}{c}33.67 \\
(10.81)\end{array}$ & 49.39 & $\begin{array}{l}-19.71 \\
(17.66)\end{array}$ & $\begin{array}{l}16.74 \\
(13.64)\end{array}$ \\
\hline Aggregate & 162.18 & $\begin{array}{r}1.064 \\
(27.39)\end{array}$ & $\begin{array}{c}21.49 \\
(18.32)\end{array}$ & 102.66 & $\begin{array}{r}6.267 \\
(28.68)\end{array}$ & $\begin{array}{l}24.27 \\
(19.39)\end{array}$ \\
\hline Brazil & & $\begin{array}{c}\text { (Calibrated } \\
\text { barrier) }\end{array}$ & & & $\begin{array}{c}\text { (Calibrated } \\
\text { barrier) }\end{array}$ & \\
\hline$\overline{10 Y}$ & 67.33 & $\begin{array}{l}-11.18 \\
(22.50)\end{array}$ & $\begin{array}{l}25.95 \\
(17.09)\end{array}$ & 51.03 & $\begin{array}{l}-10.63 \\
(44.77)\end{array}$ & $\begin{array}{c}34.01 \\
(30.99)\end{array}$ \\
\hline $15 Y$ & 56.18 & $\begin{array}{l}-1.792 \\
(15.93)\end{array}$ & $\begin{array}{l}13.21 \\
(9.078)\end{array}$ & 46.37 & $\begin{array}{l}-8.041 \\
(27.79)\end{array}$ & $\begin{array}{l}23.18 \\
(17.32)\end{array}$ \\
\hline $20 Y$ & 71.6 & $\begin{array}{r}2.039 \\
(17.38)\end{array}$ & $\begin{array}{l}14.81 \\
(9.326)\end{array}$ & 32.01 & $\begin{array}{l}-4.019 \\
(19.23)\end{array}$ & $\begin{array}{l}15.11 \\
(12.56)\end{array}$ \\
\hline $30 Y$ & 80.69 & $\begin{array}{l}-0.267 \\
(17.27)\end{array}$ & $\begin{array}{l}14.33 \\
(9.651)\end{array}$ & 34.47 & $\begin{array}{l}-0.692 \\
(21.59)\end{array}$ & $\begin{array}{l}23.27 \\
(15.28)\end{array}$ \\
\hline Aggregate & 69.84 & $\begin{array}{l}-2.592 \\
(18.37) \\
\end{array}$ & $\begin{array}{l}16.92 \\
(11.65)\end{array}$ & 38.93 & $\begin{array}{r}-6.217 \\
(35.03) \\
\end{array}$ & $\begin{array}{c}23.43 \\
(20.42)\end{array}$ \\
\hline Mexico & & $\begin{array}{l}\text { (Reference } \\
\text { barrier) }\end{array}$ & & & $\begin{array}{l}\text { (Reference } \\
\text { barrier) }\end{array}$ & \\
\hline$\overline{10 Y}$ & 58.05 & $\begin{array}{l}-18.48 \\
(28.37)\end{array}$ & $\begin{array}{l}27.86 \\
(19.25)\end{array}$ & 443.51 & $\begin{array}{l}311.8 \\
(97.14)\end{array}$ & $\begin{array}{l}311.8 \\
(97.14)\end{array}$ \\
\hline $15 Y$ & 59.7 & $\begin{array}{l}-22.62 \\
(25.54)\end{array}$ & $\begin{array}{l}30.21 \\
(15.87)\end{array}$ & 287.54 & $\begin{array}{l}222.0 \\
(110.3)\end{array}$ & $\begin{array}{l}222.0 \\
(110.3)\end{array}$ \\
\hline $20 Y$ & 60.8 & $\begin{array}{l}-25.97 \\
(21.47)\end{array}$ & $\begin{array}{l}30.79 \\
(13.70)\end{array}$ & 176.3 & $\begin{array}{l}103.6 \\
(34.86)\end{array}$ & $\begin{array}{l}103.6 \\
(34.86)\end{array}$ \\
\hline $30 Y$ & 89.11 & $\begin{array}{l}-45.89 \\
(12.66)\end{array}$ & $\begin{array}{l}45.89 \\
(12.66)\end{array}$ & 89.23 & $\begin{array}{c}55.08 \\
(29.03)\end{array}$ & $\begin{array}{c}55.55 \\
(28.12)\end{array}$ \\
\hline Aggregate & 68.79 & $\begin{array}{l}-28.62 \\
(22.72)\end{array}$ & $\begin{array}{l}36.99 \\
(15.58)\end{array}$ & 279.01 & $\begin{array}{l}173.9 \\
(78.19)\end{array}$ & $\begin{array}{l}171.2 \\
(76.51)\end{array}$ \\
\hline Mexico & & $\begin{array}{c}\text { (Calibrated } \\
\text { barrier) }\end{array}$ & & & $\begin{array}{c}\text { (Calibrated } \\
\text { barrier) }\end{array}$ & \\
\hline$\overline{10 Y}$ & 42.87 & $\begin{array}{c}-5.848 \\
(30.75)\end{array}$ & $\begin{array}{l}24.79 \\
(19.10)\end{array}$ & 56.94 & $\begin{array}{l}-17.89 \\
(44.10)\end{array}$ & $\begin{array}{c}36.76 \\
(20.24)\end{array}$ \\
\hline $15 Y$ & 45.49 & $\begin{array}{r}4.349 \\
(31.37)\end{array}$ & $\begin{array}{l}24.76 \\
(19.75)\end{array}$ & 60.48 & $\begin{array}{r}0.884 \\
(26.26)\end{array}$ & $\begin{array}{l}33.96 \\
(31.42)\end{array}$ \\
\hline $20 Y$ & 40.41 & $\begin{array}{r}2.398 \\
(26.33) \\
\end{array}$ & $\begin{array}{c}19.29 \\
(18.07)\end{array}$ & 39.6 & $\begin{array}{c}-1.700 \\
(24.17)\end{array}$ & $\begin{array}{c}19.28 \\
(14.68)\end{array}$ \\
\hline
\end{tabular}


Table 6 continued

\begin{tabular}{|c|c|c|c|c|c|c|}
\hline & \multicolumn{3}{|c|}{ Precrisis Period } & \multicolumn{3}{|c|}{ Postcrisis Period } \\
\hline & \begin{tabular}{|c|} 
RMS Error \\
(basis points)
\end{tabular} & Percentage Error & $\begin{array}{c}\text { Absolute } \\
\text { Percentage Error }\end{array}$ & $\begin{array}{c}\text { RMS Error } \\
\text { (basis points) }\end{array}$ & Percentage Error & $\begin{array}{c}\text { Absolute } \\
\text { Percentage Error }\end{array}$ \\
\hline \multirow[t]{2}{*}{$30 Y$} & 37.85 & -3.782 & 15.03 & 37.75 & 3.046 & 16.77 \\
\hline & & (18.09) & $(10.76)$ & & $(20.85)$ & $(12.76)$ \\
\hline \multirow[t]{2}{*}{ Aggregate } & 41.80 & -0.784 & 20.97 & 49.62 & -3.701 & 26.55 \\
\hline & & $(27.54)$ & $(17.21)$ & & $(29.96)$ & $(22.68)$ \\
\hline Turkey & & $\begin{array}{c}\text { (Reference } \\
\text { barrier) }\end{array}$ & & & $\begin{array}{c}\text { (Reference } \\
\text { barrier) }\end{array}$ & \\
\hline \multirow[t]{2}{*}{$\overline{10 Y}$} & 108.8 & 53.61 & 56.19 & 650.17 & 264.5 & 264.5 \\
\hline & & $(62.85)$ & $(60.55)$ & & $(103.2)$ & $(103.2)$ \\
\hline \multirow{2}{*}{$15 Y$} & 120.55 & 10.63 & 30.29 & 359.45 & 127.7 & 127.7 \\
\hline & & $(39.20)$ & (27.05) & & $(54.73)$ & $(54.73)$ \\
\hline \multirow[t]{2}{*}{$20 Y$} & 77.16 & 7.874 & 25.75 & 235.41 & 92.63 & 92.64 \\
\hline & & $(29.54)$ & (16.48) & & (38.05) & (38.04) \\
\hline \multirow[t]{2}{*}{$30 Y$} & 137.95 & -31.22 & 31.44 & 112.72 & 36.97 & 41.98 \\
\hline & & $(16.20)$ & (15.77) & & $(33.10)$ & $(26.46)$ \\
\hline \multirow[t]{2}{*}{ Aggregate } & 116.69 & 7.670 & 35.67 & 393.7 & 130.4 & 131.7 \\
\hline & & $(39.86)$ & (34.24) & & $(63.60)$ & (62.83) \\
\hline Turkey & & $\begin{array}{c}\text { (Calibrated } \\
\text { barrier) }\end{array}$ & & & $\begin{array}{c}\text { (Calibrated } \\
\text { barrier) }\end{array}$ & \\
\hline \multirow[t]{2}{*}{$\overline{10 Y}$} & 133.55 & -2.822 & 36.08 & 126.95 & -22.55 & 46.40 \\
\hline & & $(48.29)$ & (32.21) & & (47.54) & $(24.80)$ \\
\hline \multirow[t]{2}{*}{$15 Y$} & 120.22 & 3.425 & 30.09 & 112.3 & -15.91 & 35.89 \\
\hline & & (37.57) & $(22.74)$ & & (38.37) & $(20.89)$ \\
\hline \multirow[t]{2}{*}{$20 Y$} & 73.97 & -2.844 & 24.71 & 88.71 & -10.87 & 28.54 \\
\hline & & (28.13) & $(13.72)$ & & $(31.61)$ & (17.39) \\
\hline \multirow[t]{2}{*}{$30 Y$} & 93.54 & 1.549 & 18.91 & 107.86 & -9.26 & 29.27 \\
\hline & & (23.07) & (13.31) & & (33.02) & (17.88) \\
\hline \multirow[t]{2}{*}{ Aggregate } & 108.9 & 0.275 & 27.18 & 109.82 & -14.65 & 35.03 \\
\hline & & $(35.32)$ & $(21.78)$ & & (38.15) & $(20.45)$ \\
\hline Colombia & & $\begin{array}{c}\text { (Reference } \\
\text { barrier) }\end{array}$ & & & $\begin{array}{c}\text { (Reference } \\
\text { barrier) }\end{array}$ & \\
\hline \multirow[t]{2}{*}{$10 Y$} & 325.88 & 96.95 & 96.95 & 153.48 & 20.55 & 52.21 \\
\hline & & $(54.26)$ & $(54.26)$ & & $(60.43)$ & (36.73) \\
\hline \multirow[t]{2}{*}{$20 Y$} & NA & NA & NA & 91.16 & -30.98 & 34.74 \\
\hline & & & & & (26.87) & (21.79) \\
\hline \multirow[t]{2}{*}{$30 Y$} & 93.69 & -18.54 & 23.02 & 58.86 & -22.78 & 24.03 \\
\hline & & $(21.22)$ & (16.26) & & (16.63) & $(14.76)$ \\
\hline \multirow[t]{2}{*}{ Aggregate } & 234.7 & 36.35 & 58.16 & 107.25 & -10.89 & 36.45 \\
\hline & & $(40.44)$ & (39.22) & & (38.98) & $(25.80)$ \\
\hline Colombia & & $\begin{array}{c}\text { (Calibrated } \\
\text { barrier) }\end{array}$ & & & $\begin{array}{c}\text { (Calibrated } \\
\text { barrier) }\end{array}$ & \\
\hline \multirow{2}{*}{$10 Y$} & 109.68 & -2.256 & 31.49 & 95.3 & -37.32 & 52.12 \\
\hline & & $(38.71)$ & $(22.61)$ & & $(46.69)$ & (29.28) \\
\hline \multirow[t]{2}{*}{$20 Y$} & NA & NA & NA & 70.72 & -8.014 & 24.99 \\
\hline & & & & & (27.75) & (14.47) \\
\hline \multirow[t]{2}{*}{$30 Y$} & 86.91 & 2.431 & 21.98 & 33.9 & 4.364 & 14.51 \\
\hline & & (25.03) & $(12.21)$ & & (18.09) & (11.65) \\
\hline
\end{tabular}


Table 6 continued

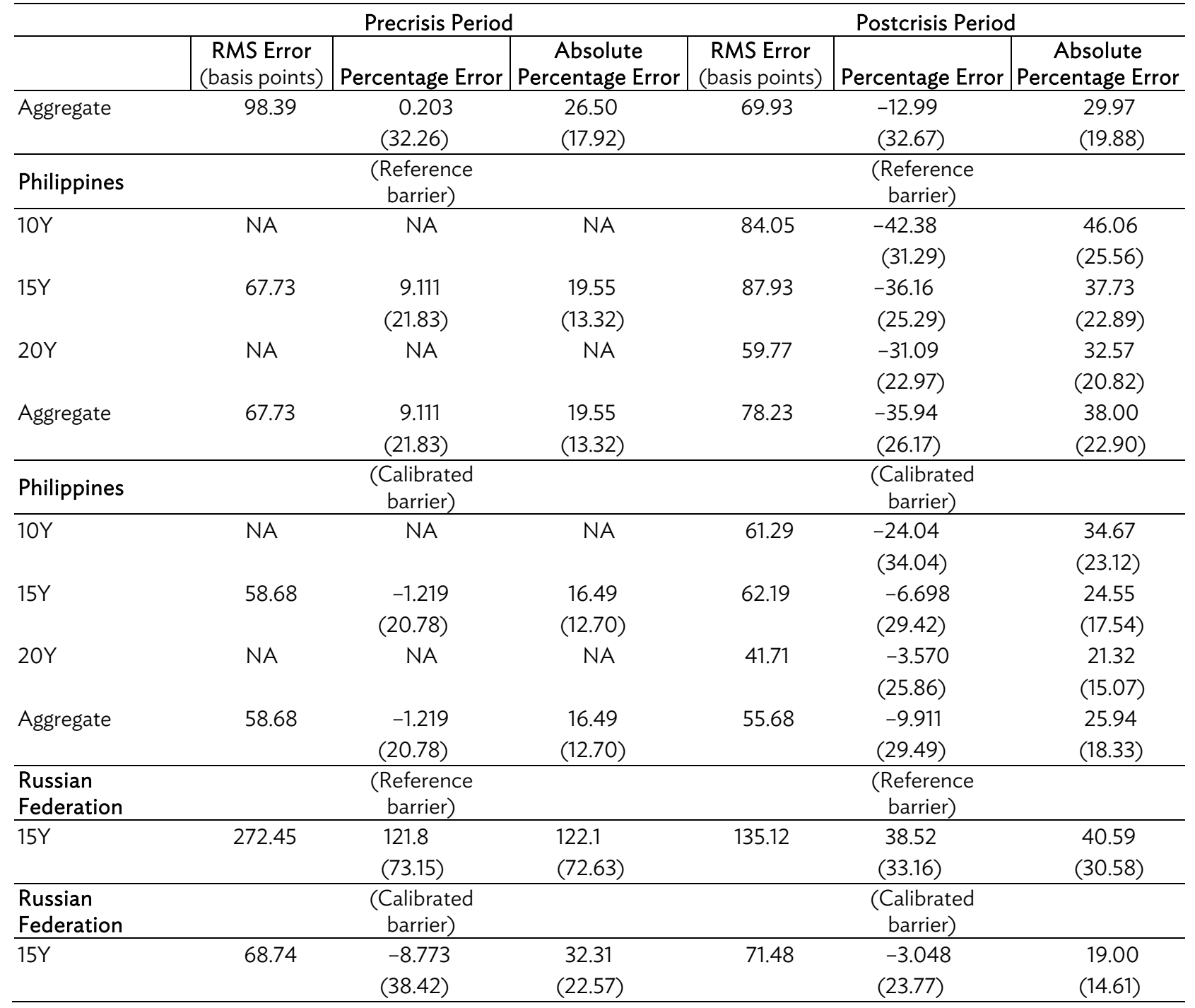

NA = not available, $\mathrm{RMS}=$ root mean square

Note: The numbers in parentheses are the standard deviations of the errors.

Source: Authors' estimates.

For pricing the Brazilian sovereign bonds using the reference barrier, root-mean-square (RMS) errors are about 72-263 bps (with the aggregate of 162 bps) and 32-116 bps (with the aggregate of 103 bps) for different tenors in the precrisis and postcrisis periods, respectively. The corresponding absolute percentage errors are 18\%-34\% (with the aggregate of 21\%) and 17\%-29\% (with the aggregate of 24\%). Using the calibrated barriers, the RMS errors drop to the ranges of 56-81 bps (with the aggregate of 69 bps) and 32-51 bps (with the aggregate of $39 \mathrm{bps)} \mathrm{in} \mathrm{the} \mathrm{precrisis} \mathrm{and} \mathrm{postcrisis} \mathrm{periods,} \mathrm{respectively.}$ The corresponding absolute percentage errors are in the ranges of 13\%-26\% (with the aggregate of 17\%) and $15 \%-34 \%$ (with the aggregate of $23 \%$ ).

The results show that the RMS errors are smaller in the postcrisis period than in the precrisis period. However, the absolute percentage errors are larger in the postcrisis period, indicating that the differences in the RMS errors are mainly due to credit spreads in the postcrisis period (with the mean about $2 \%$ ) being lower than in the precrisis period (with the mean about $3.5 \%$ ) as shown in Table 1. As 
expected, the performance of the model based on the calibrated barriers is better than that based on the reference barrier. However, if the ranges and aggregates of errors for the two types of barriers in the postcrisis period are compared, the use of the calibrated barriers does not substantially outperform compared with the reference barrier. The percentage errors indicate that the model with the calibrated barrier tends to generate lower credit spreads in both the precrisis and postcrisis periods, at $-2.6 \%$ and $-6.2 \%$ in aggregate. While the magnitudes are smaller than the standard deviations, this indicates a marginal systematic negative (positive) bias of the model for the pricing of the bond spreads (prices).

For Mexican sovereign bonds, the RMS errors with the reference barrier are in the ranges of 58$89 \mathrm{bps}$ (with the aggregate of $69 \mathrm{bps}$ ) and 89-444 bps (with the aggregate of $279 \mathrm{bps)}$ in the precrisis and postcrisis periods, respectively. The corresponding absolute percentage errors are $28 \%-46 \%$ (with the aggregate of $37 \%$ ) and $56 \%-312 \%$ (with the aggregate of $171 \%$ ). The poorer performance of the model in the postcrisis period reflects that the reference barrier is very different from the level of the exchange rate triggering default. Using the calibrated barriers, the RMS errors in the precrisis and postcrisis periods drop to 38-45 bps (with the aggregate of $42 \mathrm{bps}$ ) and 38-60 bps (with the aggregate of $50 \mathrm{bps}$ ), respectively. The corresponding absolute percentage errors fall in the ranges of $15 \%-25 \%$ (with the aggregate of $21 \%$ ) and $17 \%-37 \%$ (with the aggregate of $27 \%$ ). The performance of the model for Mexican sovereign bonds is not very different in the precrisis and postcrisis periods, while the magnitudes of their errors are similar to those of Brazilian sovereign bonds. In addition, the aggregate percentage errors indicate that the model with the calibrated barriers tends to generate lower credit spreads in the postcrisis period, but the error magnitude of $-3.7 \%$ is lower than that of Brazilian bonds.

The performance results for the sovereign bonds of Turkey, Colombia, the Philippines, and the Russian Federation are qualitatively similar to those for Brazil and Mexico in general. Using the calibrated barriers, their aggregate absolute percentage errors are in the range of $16 \%-32 \%$ and $19 \%-35 \%$ in the precrisis and postcrisis periods, respectively. The errors are not much different from those for Brazil (17\% and $23 \%$ ) and Mexico (21\% and 27\%). Their percentage errors using the calibrated barriers are mostly negative, in the range of $-14.7 \%-0.3 \%$, reflecting a marginal systematic negative (positive) bias of the model for the pricing of bond spreads (prices) particularly in the postcrisis period. The generally poorer performance of the model using the reference barriers (in particular, for Turkey in the postcrisis period) demonstrates that the performance is sensitive to the setting of the default barriers.

For a broad assessment of the performance of the proposed model for pricing sovereign bonds, its pricing errors are compared with those of the structural models for corporate bonds. Eom, Helwege, and Huang (2004) empirically test five structural models of corporate bond pricing which are considered typical, including those of Merton (1974), Geske (1977), Longstaff and Schwartz (1995), Leland and Toft (1996), and Collin-Dufresne and Goldstein (2001). They implement the models using a sample of 182 bond prices from firms with simple capital structures during 1986-1997. The mean absolute percentage errors of model credit spreads in the study are 78\% for the Merton model, $66 \%$ for the Geske model, $97 \%$ for the Longstaff-Schwartz model, 146\% for the Leland-Toft model, and 170\% for the Collin-Dufresne-Goldstein model. While pricing sovereign and corporate bonds based on the structural approach produces different pricing errors, the performance of the proposed sovereign bond pricing model is no worse than that of the structural models for pricing corporate bonds. 


\section{CONCLUSIONS}

Using data on emerging markets, including Brazil, Colombia, Mexico, the Philippines, the Russian Federation, and Turkey, before and after the global financial crisis, the empirical results show that the exchange rates of their currencies have adequate power to explain their US dollar-denominated sovereign bond prices, particularly in the postcrisis period. Based on an analogy between an economy's currency price and a firm's stock price, this paper develops a two-factor pricing model in closed-form solutions for the sovereign bonds with default at or prior to maturity (i.e., a default barrier), in which the correlated factors are foreign exchange rates and US risk-free interest rates that follow a double squareroot process relevant in the low interest rate environment. To incorporate forward-looking market information into the model, the currency option-implied volatility is used as the associated model parameter of the exchange rate.

Using US dollar-denominated sovereign bonds with different tenors, the numerical results from the closed-form solution with default prior to maturity show that the credit spreads generated from the pricing model broadly track changes in market credit spreads in both the precrisis and postcrisis periods. The correlations between them are positive and high especially when the calibrated default barriers are used for pricing the bonds. The corresponding absolute percentage errors vary among the bonds. For example, the aggregate absolute percentage errors for Brazil in the precrisis and postcrisis periods are $17 \%$ and $23 \%$, respectively, while those for Turkey are $27 \%$ and $35 \%$. The percentage errors show a marginal systematic negative (positive) bias of the model for pricing bond spreads (prices) particularly in the postcrisis period. The magnitude of the errors is lower than that of conventional structural models for the pricing of corporate bonds. The numerical results are consistent with the empirical results that the exchange rate dynamics of the emerging market currencies are significantly related to their sovereign credit spreads.

The results support the findings of a strong relationship between emerging markets' sovereign risk and exchange rate stability in the literature on international finance and studies about twin sovereign debt and currency crises. This paper's findings suggest that dollar-denominated sovereign bonds are directly influenced by exchange rate dynamics. This suggests that both governments and investors might be better served by issuing debt in local currency, and letting investors hedge these risks in currency markets.

Given that the model simply captures the contributions due to exchange rate dynamics, future research could develop multifactor models augmented to allow for the possible sensitivity of bond credit spreads to exchange rates and their volatility, and to depend on observable country-specific or macroeconomic variables, such as foreign reserves, which affect sovereign risk. 


\section{APPENDIX: DERIVATION}

It is not difficult to show by direct substitution that $\tilde{P}(x, y, \tau)$ satisfies the partial differential equation:

$$
\begin{aligned}
\frac{\partial \widetilde{P}}{\partial \tau}= & \frac{1}{2} \sigma_{S}^{2} \frac{\partial^{2} \widetilde{P}}{\partial y^{2}}+\rho_{S r} \sigma_{S} \widetilde{\sigma}_{r} \frac{\partial^{2} \widetilde{P}}{\partial x \partial y}+\frac{1}{2} \widetilde{\sigma}_{r}^{2} \frac{\partial^{2} \widetilde{P}}{\partial x^{2}} \\
& +\left\{\frac{1}{\sqrt{2}} \rho_{S r} \sigma_{S} \widetilde{\sigma}_{r} C(\tau)+\rho_{S r} \sigma_{S} \widetilde{\sigma}_{r} B(\tau) x+\alpha\right\} \frac{\partial \widetilde{P}}{\partial y} \\
& +\left\{\frac{1}{\sqrt{2}} \widetilde{\sigma}_{r}^{2} C(\tau)-\widetilde{\kappa}_{r}-\left[\lambda_{r}-\widetilde{\sigma}_{r}^{2} B(\tau)\right] x\right\} \frac{\partial \widetilde{P}}{\partial x}
\end{aligned}
$$

to eliminate all the terms involving first derivatives with respect to $x$ and $y$, rewrite $\tilde{P}(x, y, \tau)$ as:

$$
\begin{aligned}
\widetilde{P}(x, y, \tau) & =\exp \left\{\zeta(\tau) x \frac{\partial}{\partial x}\right\} \exp \left\{\xi(\tau) y \frac{\partial}{\partial y}\right\} \exp \left\{\omega(\tau) x \frac{\partial}{\partial y}\right\} \times \\
& \exp \left\{\Omega_{1}(\tau) \frac{\partial}{\partial x}\right\} \exp \left\{\Omega_{2}(\tau) \frac{\partial}{\partial y}\right\} Q(x, y, \tau) \\
& =Q\left(\exp \{\zeta(\tau)\} x+\Omega_{1}(\tau), \exp \{\xi(\tau)\} y+\omega(\tau) \exp \{\zeta(\tau)\} x+\Omega_{2}(\tau), \tau\right)
\end{aligned}
$$

where:

$$
\begin{aligned}
\zeta(\tau)= & \frac{1}{2} \gamma \tau+\ln \left|\frac{1-C_{0}}{1-C_{0} \exp (\gamma \tau)}\right| \\
\omega(\tau) & =\rho_{S r} \sigma_{S} \widetilde{\sigma}_{r} \int_{0}^{\tau} B\left(\tau^{\prime}\right) \exp \left\{-\zeta\left(\tau^{\prime}\right)\right\} d \tau^{\prime} \\
\Omega_{1}(\tau) & =\int_{0}^{\tau}\left[\frac{1}{\sqrt{2}} \tilde{\sigma}_{r}^{2} C\left(\tau^{\prime}\right)-\widetilde{\kappa}_{r}\right] \exp \left\{\zeta\left(\tau^{\prime}\right)\right\} d \tau^{\prime} \\
\Omega_{2}(\tau) & =\int_{0}^{\tau}\left[\frac{1}{\sqrt{2}} \rho_{S r} \sigma_{S} \tilde{\sigma}_{r} C\left(\tau^{\prime}\right)+\tilde{\alpha}\right] d \tau^{\prime} \\
& +\int_{0}^{\tau}\left[\frac{1}{\sqrt{2}} \tilde{\sigma}_{r}^{2} C\left(\tau^{\prime}\right)-\tilde{\kappa}_{r}\right] \omega\left(\tau^{\prime}\right) \exp \left\{\zeta\left(\tau^{\prime}\right)\right\} d \tau^{\prime}
\end{aligned}
$$

Then substituting equation (A.2) into equation (A.1), it can be shown that $Q(x, y, \tau)$ satisfies the two-dimensional diffusion equation:

$$
\frac{\partial Q}{\partial \tau}=\frac{1}{2} \sigma_{x}^{2}(\tau) \frac{\partial^{2} Q}{\partial x^{2}}+\rho_{x y}(\tau) \sigma_{x}(\tau) \sigma_{y}(\tau) \frac{\partial^{2} Q}{\partial x \partial y}+\frac{1}{2} \sigma_{y}^{2}(\tau) \frac{\partial^{2} Q}{\partial y^{2}}
$$


where

$$
\begin{aligned}
& \sigma_{x}^{2}(\tau)=\tilde{\sigma}_{r}^{2} \exp \{2 \zeta(\tau)\} \\
& \sigma_{y}^{2}(\tau)=\tilde{\sigma}_{r}^{2} \omega^{2}(\tau) \exp \{2 \zeta(\tau)\}+\sigma_{S}^{2}+2 \rho_{S r} \sigma_{S} \widetilde{\sigma}_{r} \omega(\tau) \exp \{\zeta(\tau)\} \\
& \rho_{x y}(\tau) \sigma_{x}(\tau) \sigma_{y}(\tau)=\rho_{S r} \sigma_{S} \tilde{\sigma}_{r} \exp \{\zeta(\tau)\}+\tilde{\sigma}_{r}^{2} \omega(\tau) \exp \{2 \zeta(\tau)\}
\end{aligned}
$$

It should be noted that since the final payoff condition is independent of the interest rate $r$ (or equivalently $x$ ), i.e., $P(S, r, 0)$ is a function of $S$ only, it is obvious that $Q(x, y, 0)$ does not depend upon $x$. Thus, by defining $f(y)=Q(x, y, 0)$, the solution can be readily obtained for equation (A.3) as follows:

$$
\begin{aligned}
Q(x, y, \tau) & =\exp \left\{\frac{1}{2} \Delta(\tau) \frac{\partial^{2}}{\partial y^{2}}\right\} Q(x, y, 0) \\
& =\frac{1}{\sqrt{2 \pi \Delta(\tau)}} \int_{-\infty}^{\infty} \exp \left\{-\frac{\left(y-y^{\prime}\right)^{2}}{2 \Delta(\tau)}\right\} f\left(y^{\prime}\right) d y^{\prime}
\end{aligned}
$$

where

$$
\Delta(\tau)=\int_{0}^{\tau} \sigma_{y}^{2}\left(\tau^{\prime}\right) d \tau^{\prime}
$$

This solution satisfies the natural boundary condition. Hence, the corresponding solution $\tilde{P}(x, y, \tau)$ is given by:

$$
\widetilde{P}(x, y, \tau)=\frac{1}{\sqrt{2 \pi \Delta(\tau)}} \int_{-\infty}^{\infty} \exp \left\{-\frac{\left[Y(x, y, \tau)-y^{\prime}\right]^{2}}{2 \Delta(\tau)}\right\} f\left(y^{\prime}\right) d y^{\prime}
$$

where

$$
Y(x, y, \tau)=y+\omega(\tau) \exp \{\zeta(\tau)\} x+\Omega_{2}(\tau)
$$




\section{REFERENCES}

Ahn, Dong-Hyun, Robert F. Dittmar, and A. Ronald Gallant. 2002. "Quadratic Term Structure Models: Theory and Evidence." Review of Financial Studies 15 (1): 243-88.

Aït-Sahalia, Yacine. 1996. "Testing Continuous-Time Models of the Spot Interest Rate." Review of Financial Studies 9 (2): 385-426.

Beaglehole, David, and Mark Tenney. 1992. "Corrections and Additions to 'A Nonlinear Equilibrium Model of the Term Structure of Interest Rates'." Journal of Financial Economics 32 (3): 345-53.

Beck, Roland. 2001. “Do Country Fundamentals Explain Emerging Market Bond Spreads?” CFS Working Paper No. 2001/02. Johann Wolfgang Goethe-Universität.

Black, Fischer, and John C. Cox. 1976. "Valuing Corporate Securities: Some Effects of Bond Indenture Provisions." The Journal of Finance 31 (2): 351-67.

Black, Fischer, and Myron Scholes. 1973. "The Pricing of Options and Corporate Liability." Journal of Political Economics 81 (3): 637-54.

Brunnermeier, Markus K., Stefan Nagel, and Lasse H. Pedersen. 2009. "Carry Trades and Currency Crashes." In NBER Macroeconomics Annual 2008, Volume 23, edited by Acemoglu, Daron, Kenneth Rogoff, and Michael Woodford. Chicago: University of Chicago Press.

Carr, Peter, and Liuren Wu. 2007. "Theory and Evidence on the Dynamic Interactions between Sovereign Credit Default Swaps and Currency Options." Journal of Banking and Finance 31 (8): 2383-403.

Cathcart, Lara, and Lina El-Jahel. 1998. "Valuation of Defaultable Bonds." Journal of Fixed Income 8 (1): $65-78$.

Claessens, Stijn, and George Pennacchi. 1996. "Estimating the Likelihood of Mexican Default from the Market Prices of Brady Bonds." Journal of Financial and Quantitative Analysis 31 (1): 109-26.

Cochrane, John H. 2005. “Money as Stock.” Journal of Monetary Economics 52 (3): 501-28.

Collin-Dufresne, Pierre, and Robert S. Goldstein. 2001. "Do Credit Spreads Reflect Stationary Exchange Rate Ratio?” The Journal of Finance 56 (5): 1929-57.

Cox, John C., Jonathan E. Ingersoll, and Stephen A. Ross. 1985. "A Theory of the Term Structure of Interest Rates." Econometrica 53 (2): 385-407.

Dreher, Axel, Bernhard Herz, and Volker Karb. 2006. "Is There a Causal Link between Currency and Debt Crises?” International Journal of Finance and Economics 11 (4): 305-25.

Duffie, Darrel, and David Lando. 2001. "Term Structure of Credit Spreads with Incomplete Accounting Information.” Econometrica 69 (3): 633-64. 
Duffie, Darrel, Lasse Heje Pedersen, and Kenneth J. Singleton. 2003. "Modeling Sovereign Yield Spreads: A Case Study of Russian Debt.” The Journal of Finance 58 (1): 119-59.

Eaton, Jonathan. 1996. "Sovereign Debt, Reputation and Credit Terms." International Journal of Finance and Economics 1 (1): 25-35.

Edwards, Sebastian. 1986. "The Pricing of Bonds and Bank Loans in International Markets - An Empirical Analysis of Developing Countries' Foreign Borrowing.” European Economic Review 30 (3): 56589.

Eichengreen, Barry, and Ashoka Mody. 2000. "What Explains Changing Spreads on Emerging-Market Debt: Fundamentals or Market Sentiment?” In Capital Flows and the Emerging Economies: Theory, Evidence and Controversies, edited by Sebastian Edwards. Chicago: University of Chicago Press.

Eichengreen, Barry, Andrew K. Rose, and Charles Wyplosz. 1996. “Contagious Currency Crises.” NBER Working Paper No. 5681.

Engle, Robert F., and Kevin Sheppard. 2001. "Theoretical and Empirical Properties of Dynamic Conditional Correlation Multivariate GARCH.” New York University Working Paper.

Eom, Young Ho, Jean Helwege, and Jing-Zhi Huang. 2004. "Structural Models of Corporate Bond Pricing: An Empirical Analysis.” Review of Financial Studies 17 (2): 499-544.

Farhi, Emmanuel, Samuel Paul Fraiberger, Xavier Gabaix, Romain Ranciere, and Adrien Verdelhan. 2009. "Crash Risk in Currency Markets." NBER Working Paper No. 15062.

Ferrucci, Gianluigi. 2003. "Empirical Determinants of Emerging Market Economies' Sovereign Bond Spreads." Bank of England Working Paper No. 205.

Frankel, Jeffrey A., and Andrew K. Rose. 1996. "Currency Crashes in Emerging Markets: An Empirical Treatment." Journal of International Economics 41 (3-4): 351-66.

Geske, Robert. 1977. "The Valuation of Corporate Liabilities as Compound Options." Journal of Financial and Quantitative Analysis 12 (4): 541-52.

Gray, Dale F., Robert C. Merton, and Zvi Bodie. 2007. "New Framework for Measuring and Managing Macrofinancial Risk and Financial Stability.” NBER Working Paper No. 13607.

Hansen, Lars Peter. 1982. "Large Sample Properties of Generalized Method of Moments Estimators." Econometrica 50 (4): 1029-54.

Herz, Bernhard, and Hui Tong. 2008. "Debt and Currency Crises-Complements or Substitutes?" Review of International Economics 16 (5): 955-70.

Hilscher, Jens, and Yves Nosbusch. 2010. "Determinants of Sovereign Risk: Macroeconomic Fundamentals and the Pricing of Sovereign Debt." Review of Finance 14 (2): 235-62.

Hui, Cho-Hoi, and Tsz-Kin Chung. 2011. "Crash Risk of the Euro in the Sovereign Debt Crisis of 20092010." Journal of Banking and Finance 35 (11): 2945-55. 
Hui, Cho-Hoi, and Chi-Fai Lo. 2002. "Valuation Model of Defaultable Bond Values in Emerging Markets." Asia-Pacific Financial Markets 9 (1): 45-60.

Hui, Cho-Hoi, Chi-Fai Lo, and Sai Wing Tsang. 2003. "Pricing Corporate Bonds with Dynamic Default Barriers." Journal of Risk 5 (3): 17-37.

Jeanneret, Alexandre. 2015. "The Dynamics of Sovereign Credit Risk." Journal of Financial and Quantitative Analysis 50 (5): 963-85.

Jones, E. Philip, Scott P. Mason, and Eric Rosenfeld. 1984. "Contingent Claims Analysis of Corporate Capital Structures: An Empirical Investigation." The Journal of Finance 39 (3): 611-25.

Kaminsky, Graciela, Saul Lizondo, and Carmen M. Reinhart. 1998. "Leading Indicators of Currency Crisis." IMF Staff Papers 45 (1).

Karlin, Samuel, and Howard M. Taylor. 1981. A Second Course in Stochastic Processes. New York: Academic Press.

Kim, Don H., and Kenneth J. Singleton. 2012. "Term Structure Models and the Zero Bound: An Empirical Investigation of Japanese Yields." Journal of Econometrics 170 (1): 32-49.

Kletzer, Kenneth M., and Brian D. Wright. 2000. "Sovereign Debt as Intertemporal Barter." American Economic Review 90 (3): 621-39.

Krugman, Paul R. 1991. "Target Zones and Exchange Rate Dynamics." Quarterly Journal of Economics 106 (3): 669-82.

Kumar, Manmohan, Uma Moorthy, and William Perraudin. 2003. "Predicting Emerging Market Currency Crashes." Journal of Empirical Finance 10 (4): 427-54.

Leippold, Markus, and Liuren Wu. 2003. “Design and Estimation of Quadratic Term Structure Models.” European Finance Review 7: 47-73.

Leland, Hayne, and Klaus Bjerre Toft. 1996. "Optimal Capital Structure, Endogenous Bankruptcy, and the Term Structure of Credit Spreads." The Journal of Finance 51 (3): 987-1019.

Li, Haitao, and Feng Zhao. 2006. "Unspanned Stochastic Volatility: Evidence from Hedging Interest Rate Derivatives." The Journal of Finance 61 (1): 341-78.

Lo, Chi-Fai, and Cho-Hoi Hui. 2016. "Pricing Corporate Bonds with Interest Rates Following Double Square-Root Process." International Journal of Financial Engineering 3 (3). http://dx.doi.org/10.2139/ssrn.2185861.

Lo, Chi-Fai, H. C. Lee, and Cho-Hoi Hui. 2003. "A Simple Approach for Pricing Black-Scholes Barrier Options with Time-dependent Parameters." Quantitative Finance 3 (2): 98-107.

Longstaff, Francis A. 1989. "A Nonlinear General Equilibrium Model of the Term Structure of Interest Rates.” Journal of Financial Economics 23 (2): 195-224. 
. 1992. "Multiple Equilibria and Term Structure Models." Journal of Financial Economics 32 (3): 333-44.

Longstaff, Francis A., Jun Pan, Lasse H. Pedersen, and Kenneth J. Singleton. 2011. "How Sovereign is Sovereign Credit Risk?” American Economic Journal: Macroeconomics 3 (2): 75-103.

Longstaff, Francis A., and Eduardo S. Schwartz. 1995. "A Simple Approach to Valuing Risky Fixed and Floating Rate Debt.” The Journal of Finance 50 (3): 789-819.

Merton, Robert C. 1974. "On the Pricing of Corporate Debt: The Risk Structure of Interest Rates." Journal of Financial Economics 29 (2): 449-70.

Min, Hong G. 1998. "Determinants of Emerging Market Bond Spreads: Do Economic Fundamentals Matter?" World Bank Policy Research Paper No. 1899.

Modigliani, Franco, and Merton H. Miller. 1958. "The Cost of Capital, Corporation Finance and the Theory of Investment." American Economic Review 48 (3): 261-97.

Moraux, Franck. 2004. "A Closed Form Solution for Pricing Defaultable Bonds." Finance Research Letters $1(2): 135-42$.

Newey, Whitney K., and Kenneth D. West. 1987. "A Simple Positive Semi-Definite, Heteroskedasticity and Autocorrelation Consistent Covariance Matrix." Econometrica 55 (3): 703-708.

Pan, Jun, and Kenneth J. Singleton. 2008. "Default and Recovery Implicit in the Term Structure of Sovereign CDS Spreads." The Journal of Finance 63 (5) : 2345-84.

Pavlova, Ivelina, and Maria E. de Boyrie. 2015. "Carry Trades and Sovereign CDS Spreads: Evidence from Asia-Pacific Markets.” Journal of Futures Markets 35 (11):1067-87.

Reinhart, Carmen M. 2002. "Default, Currency Crises, and Sovereign Credit Ratings." World Bank Economic Review 16 (2): 151-70.

Rocha, Katia, and Francisco A. Alcaraz Garcia. 2005. "The Term Structure of Sovereign Spreads in Emerging Markets." Journal of Fixed Income 14 (4): 45-56.

Sims, Chirtopher A. 1999. "Domestic Currency Denominated Government Debt as Equity in the Primary Surplus.” Unpublished.

Vasicek, Oldrich. 1977. "An Equilibrium Characterisation of the Term Structure." Journal of Financial Economics 5 (2): 177-88. 


\section{Exchange Rate Dynamics and United States Dollar-Denominated Sovereign Bond Prices in Emerging Markets}

The exchange rates of the currencies of Brazil, Colombia, Mexico, the Philippines, the Russian Federation, and Turkey can explain the pricing of these countries' United States dollar-denominated sovereign bonds, per empirical analysis. The relationship is particularly strong after the global financial crisis of 2008-2009. A two-factor pricing model is developed with closed-form solutions for the sovereign bonds. The correlated factors in the model-foreign exchange rates and United States risk-free interest rates-follow a double square-root process relevant in a low interest rate environment. The numerical results and associated error analysis show that the model credit spreads can broadly track market credit spreads.

\section{About the Asian Development Bank}

ADB's vision is an Asia and Pacific region free of poverty. Its mission is to help its developing member countries reduce poverty and improve the quality of life of their people. Despite the region's many successes, it remains home to a large share of the world's poor. ADB is committed to reducing poverty through inclusive economic growth, environmentally sustainable growth, and regional integration.

Based in Manila, ADB is owned by 67 members, including 48 from the region. Its main instruments for helping its developing member countries are policy dialogue, loans, equity investments, guarantees, grants, and technical assistance. 